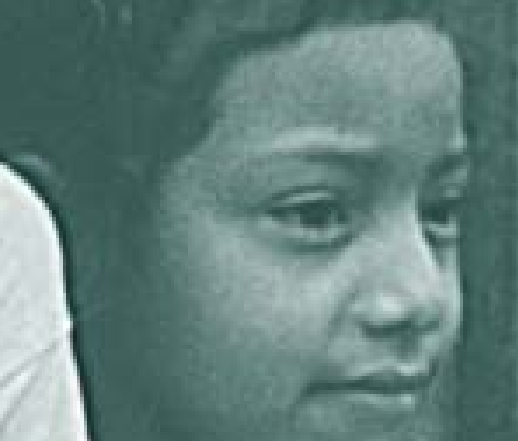




\title{
11 masculinidad y factores socioculturales asociados al compor- tamiento de los hombres frente a la paternidad en Honduras
}

\author{
M ARTHa LoRena SuAZO Y \\ Elsa Lily Caballero
}

\section{INTRODUCCIÓN}

El estudio "M asculinidad y Factores Socioculturales A sociados al Comportamiento de los $\mathrm{H}$ ombres Frente a la Paternidad en Honduras" forma parte de una investigación centroamericana coordinada por el Centro de A nálisis Sociocultural de la U niversidad C entroamericana (CA S-U CA ), M anagua N icaragua, con el financiamiento del Fondo de Población de las $\mathrm{N}$ aciones Unidas (UNFPA) como parte del Proyecto Regional "Educación Reproductiva y Paternidad Responsable en el Istmo Centroamericano de la Comisión Económica Para A mérica Latina (CEPA L)".

\section{El Problema}

Pese a que no existen estudios que den cuenta cómo viven la sexualidad y la reproducción los hondureños, y a que tampoco existen cifras estadísticas oficiales, un estudio de la CEPA L expresa que en $\mathrm{H}$ onduras aproximadamente un $25 \%$ de los recién nacidos no cuenta con un padre legalmente reconocido. (CEPA L, 2001).

La paternidad estructural y culturalmente está inserta en un sistema de dominación masculina expresada por la cultura machista imperante, de parentesco patrilineal, que se basa en la división sexual del trabajo que restringe a la mujer a la vida privada, en donde la mayoría de las decisiones sobre la reproducción no pertenecen a una concepción de planificación de la vida, o a un acuerdo de pareja.

Un comportamiento socialmente diferenciado como responsable 0 irresponsable por parte de los hombres frente a la paternidad agudiza la situación socioeconómica existente en el país y particularmente la situación de la familia. En Honduras un cuarto de los hogares son incompletos y 25 de cada 100 hogares están bajo la total responsabilidad de la mujer. A ño con año, cientos de niños y niñas que no tienen un padre que les solvente sus necesidades básicas, se incorporan al trabajo asal ariado para contribuir con la sobrevivencia del hogar, viéndose obligados a abandonar los estudios. Se sabe aho- ra que buena parte del rendimiento educativo de los niños está fuertemente influido por las características de la familia.

Existen condiciones estructurales y culturales que condicionan el comportamiento masculino respecto a la paternidad. El estudio hace una aproximación a las concepciones que tienen los hombres con relación a la masculinidad y la paternidad, desde la perspectiva del análisis sociocultural y con enfoque de género. Tomando en cuenta que la cultura masculina comprende un conjunto de representaciones 0 ideas sobre el mundo y la sociedad en que viven los hombres, así como de realidades más particulares como la concepción de estos mismos actores sobre la sexualidad, la reproducción y la paternidad, entendida ésta como un hecho biológico y cultural.

\section{Los 0 bjetivos}

El estudio tiene como objetivo general contribuir a la formulación de políticas integrales y a una intervención más eficaz sobre la problemática de la paternidad en $\mathrm{H}$ onduras.

Los objetivos específicos son:

1. Identificar las representaciones quetien en los hombres hondureños hoy sobre la masculinidad, la reproducción, la sexual idad, la familia y la paternidad.

2. 0 bservar a qué factores 0 variables pueden estar asociadas dichas representaciones 0 idealidades de los entrevistados.

3. A nalizar el comportamiento de estos mismos actores respecto a la reproducción, la sexualidad y la paternidad.

4. Hacer recomendaciones que contribuyan a la formulación de políticas y a guiar futuras intervenciones sobre el tema.

Se trata de una investigación cualitativa, que hace uso de técnicas de recopilación de datos cuantitativos y cualitativos: encuestas, entrevistas y grupos focales.

\section{Cobertura del estudio}

Este estudio se realizó a nivel nacional. En 18 municipios ubi- 
cados en cinco zonas geográficas del país: zona norte, zona central, zona occidental, zona oriental y zona sur.

Se aplicaron 1,200 encuestas a hombres mayores de 15 años, $50 \%$ a padres y $50 \%$ a no padres, $50 \%$ residentes en el área urbana y $50 \%$ residentes en el área rural. Se realizaron 36 entrevistas a hombres con diferentes características. R esidentes en el área urbana y en el área rural y 10 grupos focales, ocho con hombres y dos con mujeres.

\section{MARCO DE REFERENCIA}

\subsection{La Paternidad Como Construcción Sociocultural}

$\mathrm{H}$ istóricamente la normatividad jurídica ha sido cómplice de comportamientos responsables o irresponsables por parte de los padres, pero vistos como naturales. U na herencia negativa de la colonia, ser o no personas, tener o no derechos, no obstante, las leyes han ido cambiando, un proceso necesario en las sociedades, evolucionan y se actualizan. Como individuos e individuas también cambia el panorama respecto al goce y disfrute de los derechos o por lo menosal disfrute limitado de los mismos.

Plantean A latorre y Luna que la paternidad es estructurada, definida e interpretada en un contexto sociocultural con sus distancias sociales y dimensiones. $Y$, para entender como se define la paternidad en un contexto determinado, se hace necesario considerar lo que comparten y lo que distingue a los diferentes grupos humanos: edad, etnia, orígenes social es y sector de residencia ya que las prácticas y significados de la paternidad no son homogéneas y universales. Por consiguiente se hace necesario reconocer la multiplicidad de representaciones, prácticas e interpretaciones que los hombres hacen de su masculinidad y de la paternidad. (A latorre, Rico, 2000).

En este estudio se considera que la paternidad es una posición y función que va cambian do históricamente y tiene variaciones notables de una cultura a otra, así como en las distintas clases social es y etnias dentro de un mismo país. Tiene asimismo especificidades de acuerdo a las particulares historias de vida de los hombres, y significados distintos a lo largo del ciclo de vida de un mismo hombre.

Por tanto se considera que la paternidad cambia según las expectativas, la cultura, las necesidades económicas y las propias experiencias de los hombres como padres y como hijos. Enten demos que tradicional mente la respon sabilidad de los hombres frente a su familia ha sido la de proveedor en un sentido económico y la de no involucramiento en el cuidado y desarrollo temprano de los hijos, ni de dar muestra de cariño, por considerarse esto como una responsabilidad propia de las mujeres. También ha sido una responsabilidad tradicional de los hombres ejercer control sobre la conducta de sus hijas e hijos y de manera especial sobre la conducta sexual. La responsabilidad de socializar a los hijos e hijas tradicional mente no ha sido asumida por los hombres.

\subsection{El Marco Legal de la Paternidad}

La condición de paternidad es un estado que deviene en derechos y obligaciones. En H onduras no existe una ley específica sobre la paternidad, sin embargo, en sentido amplio existe un cuerpo legal que contiene disposiciones jurídicas relativas a los derechos y deberes que nacen de la paternidad, Ia C onstitución de la República, el Código Civil, el Código de Familia, el Código de La N iñez y La A dolescencia, la Ley Contra la Violencia Doméstica y el Código Penal, son las principales leyes que contemplan disposiciones relativas a la paternidad.

LaC onstitución dela R epública vigente ${ }^{43}$ no contiene un apartado sobre la familia, sin embargo, dentro de todo su articulado se encuentran regulaciones sobre la misma. En el Título III se declara que el fin supremo de la sociedad y del Estado es la persona humana, todos los hombres nacen libres e iguales en derechos, son los principios fundamentales, declara que la familia, el matrimonio, la maternidad y la infancia están bajo la protección del Estado, A rt.111.

En lo concerniente a la paternidad y la filiación, todos los hijostienen los mismos derechos y deberes, constitucionalmente no se reconocen cal ificaciones sobre la natural eza de la filiación. Se contempla que en ningún registro o documento referente a la filiación se consignará declaración alguna diferenciando los nacimientos ni señalando el estado civil de los padres (A rt. 114). El derecho para solicitar la investigación de la paternidad corresponde al hijo y a sus descendientes, así como al padre o madre que lo hubiere reconocido.

En lo atinente a la familia la legislación ha ido evolucionando paulatinamente, original mente todos los aspectos legal es relacionados con la familia estaban contenidos en el Libro I de las Personas del C ódigo C ivil promul gado en 1906, ${ }^{44}$ en la referida ley se contemplaban medidas que colocaban a la mujer y a los hijos en una situación de desigualdad jurídica, por ejemplo, en lo que se refería a la patria potestad de los hijos ésta pertenecía al padre, sólo extraordinariamente la mujer era poseedora de ese derecho; existía diferenciación en cuanto al hijo natural y al hijo legítimo.

Con la aprobación del Código de Familia en 1984 se mejoró la situación jurídica de la mujer y de los hijos; pese a ello, aún subsisten elementos patriarcales que siguen produciendo efectos discriminatorios. No obstante, el Código de Familia ha permitido que los derechos de las mujeres y de los hijos sean más visibles.

En el Código de Familia se contempla el derecho de Pensión de A limentos. En los artícul os comprendidos del 206 al 226, se expresa que los alimentos comprenden lo necesario para el sustento, habitación, vestido y mantenimiento de la salud del alimentado; cuando éste sea menor, los alimentos incluirán, además lo necesario para su educación. El/la juez(a) es el/la que dispone la cuantía y forma en que se deberán pagar los alimentos.

Con la emisión del Código de Familia se crean a nivel nacional los juzgados de familia. Estos juzgados son instancias especial izadas dentro del poder judicial para atender todas las peticiones que se presentan en materia de familia. 
Pese a todos estos avances aún subsisten en la legislación y en la institucionalidad elementos que le impiden a las personas tener un goce pleno de sus derechos y que van en detrimento de la familia. A ún hoy día existen zonas en el país que no cuentan con un juzgado de familia.

En 1996 seaprobó el C ódigo de la N iñez y la A dolescencia, un instrumento jurídico que podría facilitar las relaciones entre padres e hijos. La elaboración y debate del Código ha facilitado un elevamiento de la conciencia pública respecto a los derechos de los niños(as) y los/asjóvenes.

La Ley en Contra de la Violencia Doméstica es un logro más de los movimientos de mujeres. Se crea con el propósito de proteger a la mujer de todas las formas de violencia a la que está expuesta como ser violencia sexual, violencia física, violencia sicológica y violencia patrimonial. La ley provee de formas para proteger a la mujer y devolverle sus derechos.

\section{REPRESENTACIONES Y PERCEPCIONES DE HOMBRES PA- DRES Y NO PADRES}

Se presentan a continuación los resultados de la encuesta aplicada a hombres padres y no padres mayores de 15 años. Se ha tratado de integrar al análisis los testimonios producto de las entrevistas y los resultados de los grupos focales; asimismo se presentan algunos elementos teóricos relacionados.

Para este estudio, el tema de las representaciones de los hombres se recupera a partir de la Encuesta "M asculinidad y Paternidad" conteniendo una serie de proposiciones, relacionadas con aspectos sociales, religiosos, familia, masculinidad, reproducción y paternidad. Elementos que constituyen un núcleo básico de la construción de identidad y de formas de comportamiento ante eventos de la vida humana. U na de las posibles clasificaciones ${ }^{45}$ de las representaciones es en tradicionales, modernas y en transición. Las primeras se apegan a elementos idiosincráticos de larga tradición en una sociedad, las modernas son las que están influenciadas por nuevas formas de comportamiento social y las que están en transición son las que asumiendo nuevas formas de pensar y actuar ponen de manifiesto sus creencias y valores basados en la tradición.

\section{Sobre algunas características de los encuestados}

Estado civil. El estado civil de los encuestados al momento de levantar la información era: solteros (35.5\%), casados $32.4 \%$, en unión libre $26.9 \%$, separados $3.2 \%$, viudos $1.2 \%$ y el resto en menor proporción divorciados.

Escolaridad. Según los datos de la encuesta, un poco más de la mitad (51.20\%) de los entrevistados poseen estudios a nivel primario, de estos el $28.8 \%$ tiene primaria completa y el resto primaria incompleta; seguido por los que tienen estudios a nivel medio: $17.9 \%$ secundaria completa y $17.10 \%$ secundaria incompleta. En menor proporción se encuentran los anal fabetas (6.2\%), los que tienen edu- cación superior (5.9\%) y los alfabetizados (1.7\%). Se encontraba estudiando solamente el $20.6 \%$ de los encuestados.

Situación laboral. A pesar de los problemas de empleo en el país, la mayoría de los encuestados al momento de la consulta se encontraba trabajando (77.3\%). Del porcentaje de hombres que trabajan solamente el $53.4 \%$ tiene un empleo permanente.

0 cupación. Las ocupaciones son variadas, predominando las de baja calificación como son: obreros de fábrica (47\%) y agrícolas (11.3\%).

Las características ocupacional es de los entrevistados son coincidentes con los datos nacionales: se ha establecido que en $\mathrm{H}$ onduras el problema es la calidad de los empleos, bajas remuneraciones e inseguridad laboral.

Religión. En la muestra del estudio el $53.8 \%$ de los consultados es católico, en menor porcentaje evangélicos (24.5\%), y otras (1.9\%), estos porcentajes son correspondientes con la realidad del país en donde la mayoría de la población profesa la religión católica, sin embargo, la consulta registra un porcentaje de hombres que no profesan ninguna religión $19.8 \%$.

\section{SOBRE LA VISION DEL MUNDO}

Los comportamientos humanos siempre han estado asociados a formas específicas de concebir el mundo, las formas que adquieren nuestras relaciones cotidianas están por lo general sustentadas en percepciones individuales que son producto de construcciones histórico colectivas, donde se van combinando ideas de larga tradición ancestral con las que provocan los rápidos cambios a que se han visto sometidas nuestras sociedades.

\subsection{Representaciones Sobre A spectos Sociales}

La vida humana y el quehacer científico se ha construido desde lo que A ugusto Serrano:1992 Ilama "Los Ó rdenes de la Realidad" , el primer orden, el natural, que existe independientemente de la conciencia humana y el segundo orden, el social, construido por la conciencia humana y que articula de una forma específica al primer orden, según praxis históricas.

Para aproximarnos a la cultura de los hombres padres y no padres, se consideran variables relacionadas a los hechos naturales, ya que el entorno humano es a la vez natural y social y las bases de las visiones del mundo se construyen principalmente alrededor de estos dos temas ( O rtega H egg y otros:2000). Las formas de pen sar respecto a las relaciones con la natural eza pueden indicar sus mentalidades.

Los resultados de la investigación muestran que entre los hombres encuestados no existe unanimidad en las respuestas dadas a las proposiciones.

Por ejemplo el $37.8 \%$ de los consultados estuvo de acuerdo en que ciertas enfermedades son fruto de hechizos, mientrasque el $51.5 \%$ no. El $10.7 \%$ restante, duda o no sabe. En relación a las proposicio- 
nes el éxito en la vida es cuestión de suerte, el $57.1 \%$ estuvo de acuerdo y el $37.8 \%$ no. En menor proporción los que dudan y no saben y las catástrofes naturales son un castigo divino, el $56.3 \%$ estuvo de acuerdo y el $33.6 \%$ no.

En la proposición ciertas enfermedades son fruto de hechizos se presentan diferencias significativas entre los hombres residentes en el área urbana y en el área rural. El 56.2\% de los consultados en el sector urbano no está de acuerdo en que ciertas enfermedades son fruto de hechizos, siendo minoritario en el área rural (46.8\%).

Los residentes del sector urbano son losque se manifiestan más es desacuerdo. Para este grupo los procesos de morbilidad ya no se asumen como sobrenaturales, se piensa que son parte de la experiencia humana. Siguiendo a O rtega $\mathrm{H}$ egg es probable que ello se explique porque haya mayor conocimiento del origen de las enfermedades. En las formas de comprensión del mundo, el descubrir los secretos de la natural eza, no sól o amplía los conocimientos humanos, sino que cambia patrones de comportamiento y culturales, que pueden afectar a toda o una parte de las percepciones individuales, por ello, hoy en día los procesos de transición cultural, donde la ciencia contribuye a desmitificar los hechos, pareciera que se dan más rápido por la influencia y la velocidad con que fluye la información.

O tra proposición donde se presentan diferencias significativas por sector de residencia es en el éxito en la vida es cuestión de suerte. Los residentes en el área rural se manifiestan más deacuerdo $60 \%$, mientras que en el área urbana es más bajo este porcentaje $54.2 \%$ (cuadro No. 1).

O tra manera de aproximarnos a las visiones masculinas sobre el mundo es a través de sus creencias relacionadas a situaciones sociales. Las relaciones con la sociedad por lo general están asociadas a las explicaciones sobre las formas de vida de la gente, por su relevancia se han seleccionado tres variables relacionadas a aspectos que aseguran la vida material de las personas.

El creer que lo mejor es tener una empresa $(95.6 \%)$ contrasta bruscamente con la creencia que es natural que haya ricos y pobres $(89.3 \%)$, y que el creer que el éxito esté asociado a la suerte ya no sea tan firme $(57.1 \%$ de acuerdo y $37.8 \%$ no de acuerdo), nos coloca frente a mentalidades que han cambiado para al ejarse de un pensamiento mítico tradicional, no obstante que las relaciones sociales siguen tomándose como naturales, podemos asumir que se han generalizado las relaciones mercantiles e individualistas.
Probablemente, las condiciones económicas y las exigencias de la sobre vivencia estén presionan do para una forma de vida determinada por el consumo, donde aún no termina por rechazarse totalmente viejas formas de pensar sobre los aspectos de la vida, pero la realidad presiona por adquirir nuevas mentalidades. (C uadro $\mathrm{N} 0$. 2).

Se observan diferencias en las mentalidades de los padres y no padres con relación a la proposición del éxito en la vida es cuestión de suerte. A parentemente son más pragmáticos los padres ( $39.5 \%$ de acuerdo) que los no padres ( $53.7 \%$ de acuerdo), ya que los segundos aún no experimentan lo que significa la responsabilidad económica. En los padres es una opinión basada en la experiencia.

En función de la edad, las diferencias entre los hombres entrevistados no son significativamente diferentes, se registran diferencias en los hombres respecto a la visión del mundo, el fenómeno de una mentalidad en transición se empieza a percibir en mayor proporción en los de menor edad. En la disyuntiva de asumir nuevas ideas cuando aún lo tradicional es muy fuerte, contribuye a reafirmar que la población hondureña, y especialmente los hombres de menor edad poseen una mentalidad menos conservadora que los de mayor edad.

\section{Cuadro No. 1. Representaciones de los Hombres de sus Relaciones con la Naturaleza}

$\begin{array}{lllll}\text { PROPOSICIONES } & \text { DE } & \text { NO } & \text { DUDO } & \text { NO } \\ & \text { ACUERDO } & \text { ACUERDO } & & \text { SABE } \\ \text { Ciertas enfermedades } & 454 & 618 & 80 & 48 \\ \text { son fruto de hechizos } & (37.8 \%) & (51.5 \%) & (6.7 \%) & (4.0 \%) \\ \text { El éxito en la vida es } & 685 & 453 & 54 & 8 \\ \text { cuestión de suerte } & (57.1 \%) & (37.8 \%) & (4.5 \%) & (0.7 \%) \\ \text { Las catástrofes naturales } & 676 & 403 & 73 & 48 \\ \text { son un castigo divino. } & (56.3 \%) & (33.6 \%) & (6.1 \%) & (4.0 \%)\end{array}$

Fuente: Encuesta CASC-UCA -FNUAP - CEPAL. Masculinidad y Paternidad, Honduras, mayo 2002.

Cuadro No. 2. Representaciones de los Hombres de sus Relaciones con la Sociedad

\begin{tabular}{|lllll|}
\hline PROPOSICIONES & $\begin{array}{l}\text { DE } \\
\text { ACUERDO }\end{array}$ & $\begin{array}{l}\text { NO } \\
\text { ACUERDO }\end{array}$ & DUDO & $\begin{array}{c}\text { NO } \\
\text { SABE }\end{array}$ \\
\hline $\begin{array}{llll}\text { Lo mejor es tener } \\
\text { empresa propia }\end{array}$ & 1147 & 31 & 12 & 10 \\
El éxito en la vida es & $(95.6 \%)$ & $(2.6 \%)$ & $(1.0 \%)$ & $(0.8 \%)$ \\
cuestión de suerte. & $(57.1 \%)$ & $(37.8 \%)$ & $(4.5 \%)$ & 8 \\
Es natural que haya & 1072 & 101 & 19 & 8 \\
ricos y pobres & $(89.3 \%)$ & $(8.4 \%)$ & $(1.6 \%)$ & $(0.7 \%)$ \\
\hline
\end{tabular}

Fuente: Encuesta CASC-UCA -FNUAP - CEPAL. Masculinidad y Paternidad, Honduras, mayo 2002. 


\subsection{Representaciones Sobre A spectos Religiosos}

D onde más resistencia al cambio de pensamiento ha existido, es en aquellos aspectos que nos dan seguridad y reafirman identidad y pertenencia: la religión y la identidad como seres sexuados son el ementos que ayudan a construir el sentido de la vida y saberse perteneciente a un grupo determinado.

La religión es el sustento donde la mayoría de los seres humanos encuentra el sentido de ser de las cosas. La religión, modela muchos aspectos en la vida de las personas, convirtiéndose en un factor importante en la construcción de la mental idad o la forma de pensar respecto a acontecimientos que se presentan en el mundo y en la vida de los hombres y las mujeres. D ejan en manos de Diosy de la igl esia las decisiones que competen a las relaciones que se generan a partir de la convivencia humana, por lo general los resultados de las acciones humanas son un resultado del poder divino y no de relaciones sociales, se legitima social e históricamente la determinación última del destino o de un ser superior, las consecuencias de los actos cotidianos se enajenan como respon sabilidad humana.

$M$ ás de las tres cuartas partes de los encuestados, están de acuerdo en que Dios gobierna al mundo desde el cielo ( $89.1 \%$ ), este porcentaje es similar entre los hombres padres y los no padres. El Dios arriba y el hombre abajo, evidencia una relación de poder en la que Dios decide todo.

Este mismo grupo de hombres (87.3\%) manifiesta estar de acuerdo en que la iglesia tiene derecho de prohibir lo malo e impulsar lo bueno, estos porcentajes están vinculados con los hombres que dijeron que pertenecían a alguna religión (80.2\%), probablemente los que estén dudando sean los que dijeron no pertenecer a ninguna religión (19.8\%). Q ueda evidenciado el peso de las creencias religiosas y la influencia de la I glesia en sus modos de pensar.

Estas respuestas son correspondientes a un pensamiento de apoyo a la institucional idad de la iglesia. La influencia institucional en la toma de decisiones tanto a nivel personal como a nivel de algunas instituciones públicas y privadas está siempre presente y aunque no se trate de procesos lineales, se pone de manifiesto por parte de la I glesia una dirección dominante,... Las autoridades, los criollos, la élite, la I glesia y el sistema de dominación proporcionaron directrices que moldean, se imponen y ofrecen la versión oficial" (C arías, M arcos: 131).

Esta influencia no es casual, este año (2002) se han cumplido 500 años de la celebración de la primera misa en $\mathrm{H}$ onduras, la llegada de la palabra de Dios, la llegada de C risto y de su Iglesia, "Luego el pueblo de indios habría de consolidarse como instrumento de control y de explotación, pero también como fábrica de la mentalidad indio cristiana". N o obstante lo dicho, hay que tomar en cuenta la existencia de otras culturas, poco se sabe del universo religioso de los garífunas en relación con el cristianismo y de cómo influye éste en la construcción de sus mentalidades. De la obra de evangelización de los M isquitos por los pastores M oravos, este lapsus se relaciona con la poca capacidad que hemos manifestado para integrar a los M isquitos a la cultura nacional hondureña. La existencia de varios grupos poblacionales vuelve más complejo el problema de la mentalidad social en nuestra población ( C arías, M arcos: 128).

Los cambios sociales y la forma como se organiza la vida cotidiana de las personas, a medida que el consumo se generaliza contribuyen a tran sformar las formas de pensar. Para poder subsistir en un mundo tan cambiante, pareciera que es más fácil aceptar ideas e incorporarlas a la visión del mundo siempre y cuando no generen conflicto de identidad y pertenencia y por ello en última instancia siempre se dependerá de una voluntad superior. Por lo general las formas de pensar diferentes coinciden con aspectos generacionales, ya que las identidades y sus formas de construcción, son diferentes ( C uadro N o. 3).

Según los resultados, al cruzar las proposiciones sobre aspectos religiosos y sector de residencia, se encuentra un pensamiento más tradicional en la forma de pensar de los hombres residentes en el espacio rural.

En las sociedades de identidad y origen agrario los controles sociales tienden a ser más cerrados que en las sociedades de mayor industrialización, por ello en éstas últimas, muchos de los valores que sirven al control social de las formas de pensar y actuar de las personas sufren cambios importantes.

En ese sentido la residencia no es un simple lugar físico, geográfico donde habitan y tienen domicilio permanente los seres humanos. Es el espacio donde crecemos, forjamos identidad y pertenencia respecto de una entidad social, la familia, la vecindad, el pueblo (Friedmann, John: 1972).

La amplitud de los contactos culturales, personas que viven siempre bajo una misma forma de organización social y de cotidianeidad individual, personas que se exponen a formas desconocidas de formas de vida, obviamente, tendrán diferencias importantes en como enfrentan el mundo, como enfrentan la vida. El aisIamiento cultural, es un factor con la fuerza suficiente para involucionar, por lo general los poblados rurales, por su aislamiento y controles sociales muy cerrados; el arcaísmo cultural es una tendencia muy fuerte que se agudiza al tener poco acceso a la educación.

Tanto los hombres que viven en el sector urbano como en el sector rural se manifiestan en altos porcentajes de acuerdo con todas las proposiciones en las que hay un predominio de las decisiones basadas en el poder divino. De igual manera se observa el peso que tien e la institucionalidad de la I glesia en las decisiones que competen a los hombres: la iglesia tiene el derecho de prohibir lo malo e impulsar lo bueno en la sociedad, donde se observa el porcentaje más bajo es en la proposición relacionada con las promesas a los santos son prácticas religiosas imprescindibles

Se encontraron diferencias significativas por sector de residencia en la proposición la I glesia tiene derecho a sancionar moralmente a los padres que no se portan bien con los hijos.

Se observa, sin embargo, que un porcentaje pequeño de 
encuestados muestran desacuerdo con las proposiciones, evidenciando un pensamiento más secularizado que concede autonomía a la realidad temporal frente a la realidad sobrenatural.

L a ausencia o la permeabilidad de los controles sociales favorece los cambios en las formas de pensar, cuando las personas tienen la oportunidad de experimentar sin mayor control social el incumplimiento de un mandato eclesial y aunque se viole la norma no pasa nada extraordinario en la vida de la persona, por ejemplo ir a misa todos los domingos es una norma católica, pero el día que no se va, tampoco ocurre nada extraordinario, este tipo de procesos personales hacen posible ir asumiendo nuevas formas de pensar.

En las áreas urbanas cambian las formas de control social, Ias relaciones impersonales sustituyen al control social más estrecho que se da en las comunidades rurales, ello contribuye a que en el sector urbano las ideas religiosas no gobiernen tan cercanamente la vida cotidiana, "Ia palabra de Dios se acata pero no se cumple".

“...y además el aborto debe estar legalizado, yo se que es pecado y todo, pero mientras no haya nacido, no debe ser una traba para que una persona, tome su decisión..."

( $H$ ombre padre de una relación clase media, sector urbano).

Revisando los resultados de la encuesta en función de la edad respecto a los aspectos religiosos que están influyendo en la visión que tienen sobre el mundo, se observan al gunas diferencias significativas. Estas diferencias se presentan en las proposiciones: la iglesia tiene derecho a sancionar moralmente a los padres que no se portan bien con los hijos y las personas no deben interferir en los embarazos o los nacimientos, porque la vida es obra de Dios. Se observa un predominio de una mentalidad tradicional en todos los rangos de edad siendo mayor este porcentaje en los hombres de mayor edad y menor edad.

El pensamiento mágico religioso constituye un factor influyente en las formas de pensar, sin distinción de edades se está de acuerdo en la mayoría de las proposiciones. En donde el pensamiento tradicional está sien do desplazado es en: las promesas a los santos son prácticas religiosas imprescindibles, siendo los hombres entre 20 a 49 años los que no están de acuerdo o ponen en duda esta proposición, la otra proposición que se aleja del pensamiento tradicional es las catástrofes naturales son un castigo divino.

Las consideraciones precedentesindican un predominio de una mentalidad tradicional en los hombres hondureños, en esta mentalidad la condición de paternidad es un factor que poco incide, sin embargo, el sector de residencia, el nivel educativo y la religión son los factores determinantes en las mentalidades de los hombres respecto a la visión del mundo.

\subsection{Perfiles Culturales de Pensamiento de los H ombres Fren- te a la Visión del Mundo}

En este estudio se buscó investigar cuáles eran las diferentes maneras de ver el mundo de los encuestados, con la finalidad de conocer el marco más general en el que se inserta la manera de pensar de los hombres padres y no padres sobre aspectos más particulares como la sexualidad, la familia, la masculinidad y la paternidad.

Para ello se contó con un programa especial Ilamado SPA D Three, aplicado y aportado a esta investigación por la coordinación regional de esta investigación. Este programa permite agrupar en perfiles cultural es de pensamiento a los encuestados según su visión del mundo.

De esta manera, los perfiles culturales o tipologías de encuestados según su visión del mundo salen de las respuestas similares que los encuestados han dado a las proposiciones.

De la aplicación del A nálisis Factorial de Correspondencias $M$ últiplesal resultado de las encuestas en el apartado correspondiente a visión del mundo, a manera de síntesis resultaron tres perfiles o tipologías culturales: tradicional, moderno y en transición de lo tradicional a lo moderno

\section{El perfil de pensamiento tradicional}

Este primer grupo incluye al mayor número de encuestados (46.58\%), está constituido por lo que podríamos denominar una visión del mundo tradicional. En esta visión del mundo predomina una concepción espacial, donde Dios está arriba y gobierna el mundo de los seres humanos, que están abajo. En esta concepción, el ser humano tiene poca autonomía y juega más bien un rol pasivo frente 
a la realidad natural y social, que no controla.

A parece asociado a encuestados que poseen un bajo nivel educativo que apenas alcanza el nivel primario o que son analfabetos, con residencia en el área rural y que se encuentran en edades mayores (más de 50 años). De él participan todos los creyentes, no estando asociado a ninguna religión en particular. Este perfil de hombres estaría dependiendo de explicaciones mágico religiosas para enfrentar la vida y de la misma manera justificando sus actuaciones en una predeterminación sobrenatural.

\section{El perfil de pensamiento moderno}

El perfil moderno, es porcentualmente menor (30.67\%), que el perfil tradicional. Se caracteriza por tener un pensamiento más analítico. La explicación que dan a los fenómenos sociales se da en el plano social y lo natural en el plano natural, ya no dejan en manos de Dios la solución de los problemas, asumen un papel más activo. Para este grupo de hombres la I gl esia poco rige su manera de pensar.

A parece asociado a encuestados que poseen educación superior o media y que están casados.

Esta forma de pensamiento asume que los seres humanos somos responsables de nuestros actos, esta postura frente al mundo puede constituir una actitud favorable ante la equidad de género al descubrir las determinaciones sociales de las relaciones entre hombres y mujeres.

\section{El Perfil de pensamiento en transición}

El perfil en transición es de un porcentaje bastante alto (22.75\%), aunque es menor que los anteriores.

Esta visión en transición no se asocia a ningún tipo de variables ilustrativas. Ello puede ser consecuencia de que este tipo de mentalidad se puede encontrar tanto en el área urbana y rural sin importar creencia religiosa, ni edad ni condición de paternidad u otra variable sociodemográfica. En este perfil participaron todos los encuestados que manifestaron no pertenecer a ninguna religión.

Los hombres que han abandonado las formas tradicionales de religiosidad, que se han separado de prácticas religiosas convencionales, les permite poner en duda el esquema dominante del pensamiento mágico religioso. La existencia de la duda los podría colocar en una posición favorable hacia las relaciones de género equitativas.

\subsection{Representaciones y Percepciones Sobre la Sexualidad}

Este apartado trata de rescatar la experiencia sexual masculina, desde una perspectiva sociocultural a partir de un conjunto de derivaciones acerca de lo que le corresponde hacer al hombre y a la mujer, introyectadas en la cultura sexual de los hondureños.

El desenvolvimiento sexual es fundamental en la identidad masculina de los hombres. En H onduras, existen muy pocos estudios que aborden la sexualidad desde la perspectiva de los varones, a excepción de la encuesta sociodemográfica Epidemiología y Salud Familiar, EN ESF, la Encuesta $\mathrm{N}$ acional de Salud $\mathrm{M}$ asculina y pequeños estudios referidos especial mente a la salud.

En lasencuestas sociodemográficas como la EN ESF y la de Salud M asculina las preguntas sobre la sexualidad, identifican comportamientos procreativos o de riesgo para la salud. La encuesta, por el tipo de instrumento que utiliza, muestreo con cuestionarios impersonales y preguntas precodificadas, no proporciona las herramientas idóneas para acercarse a la realidad de comportamientos tan sensibles como los sexuales. Sin embargo, los resultados, son muy consistentes y al menos permiten tener indicios sobre la normatividad de la sexualidad en amplios grupos (Szas: 1998).

\section{La iniciación de la sexualidad}

Para los hombresla iniciación sexual es una experiencia solitaria, sin el apoyo familiar ni escolar que les proporcione los conocimientos precisos para enten der esta etapa de la vida, Io asumen como algo prohibido, no existe por parte del sistema educativo un abordaje planificado y sistemático de la sexualidad que provea a los niños de un aprendizaje formal, por lo que se les reduce la oportunidad de vivir la sexualidad con placer y seguridad.

“... En mi casa nunca me hablaron de sexo, para mi papá y mi mamá hablar de eso era como un tabú, la verdad yo nunca tuve valor de hablar de sexo con mi papá...."

(H ombre urbano, clase popular, con hijos de una relación)

"....M ire, fíjese que cuando yo estaba soltero, nosotros nos reuníamos en el parque con unos amigos y ahí hablábamos de eso pero de a escondidas porque si nos descubrían era como un pecado...."

( $\mathrm{H}$ ombre rural, clase media, con hijos de varias relaciones)

El espacio por excelencia para abordar los temas relacionados con la sexualidad, son los amigos, es el medio de socialización más abierto que tienen los hombres desde la niñez, no ha sido ni la familia, ni la escuela. C asi siempre, los mensajes sobre la sexualidad tienen un contenido de reafirmación del machismo.

“.... Yo me sentía mal porque no había echado un polvo, porque en la escuela decían que era maricón el que no iba a Belén... C uando fui ya me sentí tranquilo y hasta me inventé unas cosas..."

( Hombre urbano, clase media, de una relación)

\section{Las relaciones sexuales como necesidad física}

La sexualidad de los hombres es construida esencialmente como un impulso natural al que hay que dejar ser, la de las mujeres en cambio, es construida como un impulso al que hay que normar. En $\mathrm{H}$ onduras se considera un hecho biológico que el hombre tenga más necesidades sexuales, quien se adjudica el derecho de tomar a las mujeres como un reto a ser vencido (Rodríguez: 2001).

La idea de la sexualidad masculina como fuerza natural, y de la sexualidad femenina como fuerza controlada explica a su vez las formas en que se conceptualizan las relaciones entre hombres y mujeres. Estas construcciones social es de control masculino de la sexualidad femenina, en parte están determinadas por la necesidad de asegurar la descendencia paterna, ya que el control de la sexualidad 
femenina es la única posibilidad y a su vez este control ha sido la base de las jerarquías y desigual dades social es entre hombres y mujeres.

A I respecto, las representaciones de los varones son relativamente homogéneas, salvo por leves diferencias por edad y condición de paternidad, en algunas proposiciones porcentajes similares de hombres se manifiestan en acuerdo (47.5\%) y desacuerdo (45.0\%) de que el hombre necesita las relaciones sexuales más que la mujer, una opinión dividida, que polariza las mentalidades de los hombres, siendo levemente mayor los hombres con una mentalidad tradicional. Y además, que en los hombres las relaciones sexuales son una necesidad física que no se puede controlar, un poco más de la mitad de los consultados ( $51.8 \%$ ) estuvo de acuerdo con esa proposición, mientras que el $45.5 \%$ no.

Los comentarios vertidos en un grupo focal con hombres padres urbanos, son similares a los resultados de la encuesta, la mayoría estuvo de acuerdo en que los hombres no pueden controlar su sexualidad, como dijo un participante para mí "todo lo que es carne al gancho" dejando entrever que su sexualidad no tiene límites.

Por otro lado, los jóvenes de clase media participantes a un grupo focal expresaron: cuando estábamos en el colegio íbamos a la casa de un compañero a enamorar a la empleada y hasta apostábamos quien se la conseguía primero, poniendo de manifiesto la concepción utilitaria que tienen algunos hombres sobre las mujeres.

En los comentarios de las mujeres urbanas participantes a un grupo focal se percibe una enorme insatisfacción al compartir su sexualidad con sus esposos o compañeros, no se sienten complacidas, se sienten usadas, las mujeres unas satisfacemos nada mas sus necesidades sexuales, otras les servimos de domésticas, criadas, profesionales etc.,

Ello pone de manifiesto que es el machismo, el sustrato ideológico que sustenta los comportamientos basados en la primacía de las necesidades sexuales masculinas frente a las femeninas, que se ha constituido en una de las bases centrales para el control social de la sexualidad, la femenina que queda atrapada en un conjunto de creencias que limitan o inhiben el comportamiento sexual de la mujer y la masculina, se ha llegado a la creencia de que es determinada por la naturaleza.

M ientras los controles de las mujeres son de carácter social y moral, los hombres quedan reducidos en su sexualidad por la irracionalidad, su natural eza de hombre es más fuerte que el raciocinio, en lo sexual los hombres no son seres pensantes, sólo responden a instintos. C on esa ideología, los hombresquedan libres de responsabilidad por sus actos sexuales, pues obedecen a su naturaleza y no a su raciocinio.

\section{Actividad y pasividad}

El comportamiento sexual activo, frente a mujeres sexual mente pasivas, así como una atracción inten sa y permanente hacia las mujeres, confirman esa hombría. El varón debe apropiarse del cuerpo de las mujeres y también de su deseo y actividad. La búsqueda sexual no solamente es una búsqueda de placer, sino un intento de colmar ansiedades, de aumentar la autoestima, de confirmar la masculinidad.

EI hombre es quien debe tomar la iniciativa en las relaciones sexuales.

Los hombres pueden tener relaciones sexuales con sus parejas aunque ellas no quieran.

EI hombre puede tener relaciones sexuales con una mujer sin compromiso.

Los vínculos entre la actividad de los hombres y la pasividad de las mujeres en las representaciones mentales de los hombres tienen trascendencias. En las proposiciones: El hombre es quien debe tomar la iniciativa en las relaciones sexual es, un poco más de la mitad estuvo de acuerdo (60.6\%); Los hombres pueden tener relaciones sexuales con sus parejas aunque ellas no quieran $87.2 \%$ de acuerdo, $36.7 \%$ no y $2.1 \%$ y $0.5 \%$ dudan o no saben; EI hombre puede tener relaciones sexuales con una mujer sin compromiso $60.8 \%$ de acuerdo, 36.7\% no está de acuerdo, en menores porcentajes están representados los que dudan y no saben.

Estas respuestas indican la forma en que los hombres experimentan las relaciones sexuales, dada su condición de género. Los hombres, como poseedores de la fuerza y del poder se consideran con derecho hacia la mujer de utilizarla sexualmente. "Las mujeres han aprendido a sentirse usadas y los hombres han aprendido a sentir que usan a las mujeres. ${ }^{46}$

En la proposición El amor es lo principal en la relación sexual, el $88.6 \%$ de los consultados está de acuerdo, el $9.9 \%$ no y en menor proporción los que dudan o no saben. Este tipo de imaginario sitúa a los hombres en una relación de pareja más estable.

Cuando los hombres se refieren al afecto, representan el amor romántico construido desde la perspectiva y necesi dades masculinas del amor. La fidelidad, la entrega, la prueba de amor, el cuidar del hombre, son entre otras las expresiones de este amor romántico masculino que ha dejado por fuera las necesi dades de amor desde la perspectiva de las mujeres. Los sentimientos como el afecto, la seguridad, el respeto, la confianza, etc. han sido definidos y aceptados socialmente por loshombres desde un concepto de amor que anula las aspiraciones personales de las mujeres y los deja en libertad para hacer con ese amor lo que les plazca.

"... La iniciativa la debo tomar yo, por supuesto que yo, y para que estoy pues.... mi mujer tiene que estar dispuesta y seguirme".

(H ombre padre, clase popular, sector urbano)

A demás de las connotaciones de género que conllevan estas representaciones, tiene implicaciones sociales, familiares y personales. A fecta la salud emocional de las mujeres, deriva en paternidad irresponsable, con las consabidas consecuencias, hijos emocionalmente afectados, con pocas posibilidades de tener un desarrollo normal, limitados económicamente, aumento de la jefatura femenina etc. 
El incremento de padecimientos relacionados con comportamientos sexuales, especialmente el SIDA, pone en constante riesgo a la mujer de contraer enfermedades de transmisión sexual. La epidemia del SIDA constituye una seria preocupación. H onduras concentra el $50 \%$ de los casos de la región, se estima que existen unas 58,000 personas seropositivas.

La epidemia se ha feminizado, la proporción de 6 hombres por 1 mujer durante los años 80 se ha modificado en los 90 de 2.1 hombres a 1 mujer; el SIDA ha pasado a ser una de las primeras causas de muerte entre las mujeres en edad fértil. Se tienen diferencias geográficas importantes, la ciudad de San Pedro Sula y sus al rededores es la más afectada, supera al 3\% de prevalencia de la población adulta (C uesta, José, 2001).

Posiblemente la epidemia del SIDA, en el futuro sea un factor decisivo en los cambios del comportamiento sexual de los hondureños, en la medida en que se tenga más información, de la magnitud del problema, la tendencia pueda ser una sola pareja, como medida de protección.

“... Yo mismo he tenido relaciones extramatrimoniales, ahora tengo una concepción muy clara sobre esto. M e parece que ese tipo de experiencias a lo único que terminan llevando es a problemas. E so roba la paz de la familia, e impide que sea feliz.

(Padre de múltiples parejas, clase media)

Este tipo de comportamiento puede estar asociado a hombres que creen que ya Ilegaron a la madurez, y un signo de ello, es tener una sola pareja, pero también puede tener una proyección de asegurar una compañera que lo cuide en su vejez, donde los resentimientos de pareja no son compatibles con la idea de una vejez tranquila.

U no sólo debe pensar en tener relaciones sexuales cuando va a casarse, $55.8 \%$ de acuerdo, $41.5 \%$ no de acuerdo. Es normal que las mujeres tengan relaciones sexuales con otros hombres, además de su pareja $17.4 \%$ de acuerdo, $81.3 \%$ no de acuerdo. Es normal que las mujeres tengan relaciones sexuales con su pareja antes del matrimonio 47.2 $\%$ de acuerdo, $50.9 \%$ no de acuerdo.

Las tres respuestas muestran una fuerte tendencia de reafirmación del control de la sexualidad femenina y del amor romántico identificado con los intereses de los hombres. A I vivir en una sociedad construida para satisfacer las necesidades masculinas a costa de la insatisfacción de las necesidadesfemeninas, es explicable como las representaciones sobre la sexualidad reafirman la construcción masculina de la sexualidad.
El pensamiento sigue siendo tradicional, se mantienen firmes varias opiniones acerca del estereotipo de la sexualidad masculina, los hombres padres y no padres la mayoría está de acuerdo en que el amor es lo principal en la relación sexual, no están de acuerdo en que las relaciones sexual es entre personas del mismo sexo son aceptables.

Son los hombres que todavía no son padres los que presentan opiniones más conservadoras y más estereotipadas, aunque el porcentaje de los no de acuerdo es relativamente alto, los no padres se manifiestan más de acuerdo por ejemplo en: EI hombre puede tener relaciones sexuales con una mujer sin compromiso (64.8\%), El hombre necesita las relaciones sexuales más que la mujer (49.0\%), En los hombres las relaciones sexuales son una necesidad física que no se puede controlar $(48.8 \%)$, El hombre es quien debe tomar la iniciativa en las relaciones sexuales ( $62.4 \%$ ), uno sólo debe pensar en tener relaciones sexuales cuando va a casarse ( $42.8 \%)$.

\section{La previsión de las enfermedades de transmisión sexual. U na preocupación emergente en el discurso masculino}

En la actualidad la previsión de las enfermedades de transmisión sexual es un tema que empieza a estar presente en los hondureños y las hondureñas, ya comentan su preocupación por el riesgo que representa tener relaciones sexual es sin protección o a través de compra de servicios sexuales, probablemente la al ta incidencia de casos de SIDA y el elevado número de muertes por esta enfermedad esté sensi bilizando a los hombres y cambian do la percepción que sobre la sexualidad poseen.

"... La práctica del sexo tiene que ser sincera vea, para evitar un riesgo, porque si yo ando detrás de una hembra que me gusta, porque para eso nacieron las hembras, y allá voy a caer en un error, porque talvez ella, a como está la situación de ahora, que sabemos haiga agarrado a otra persona que sea enfermo, vaya te fuiste papa..."

( $\mathrm{H}$ ombre padre, clase popular, sector rural)

Lo esbozado anteriormente permite observar un modelo de pensamiento tradicional dominante que reafirma una sexualidad concentrada en las necesidades definidas desde la perspectiva de lo que los hombres consideran es normal, o natural en ellos. Las formas de pensar la sexualidad mascul ina están determinando decididamente las actuaciones y representaciones sobre la reproducción, la condicionalidad del carácter natural de la sexualidad masculina que incide en la negativa al control sobre la reproducción, dejándola como proceso natural donde sólo Dios puede intervenir. 


\begin{tabular}{|lllll|}
\hline PROPOSICIONES & DE ACUERDO & NO DE ACUERDO & DUDO & NO SABE \\
\hline El amor es lo principal en la relación sexual & 1,063 & 119 & 14 & 4 \\
& $(88.6 \%)$ & $(9.9 \%)$ & $(1.2 \%)$ & $(0.3 \%)$ \\
& 1,007 & 172 & 19 & 2 \\
Las relaciones sexuales son sólo para tener hijos & $(83.9 \%)$ & $(14.3 \%)$ & $(1.6 \%)$ & $(0.2 \%)$ \\
& 729 & 440 & 25 & 6 \\
El hombre puede tener relaciones sexuales con & $(60.8 \%)$ & $(36.7 \%)$ & $(2.1 \%)$ & $(0.5 \%)$ \\
una mujer sin compromiso & 570 & 540 & 55 & 35 \\
El hombre necesita las relaciones sexuales más que la mujer & $(47.5 \%)$ & $(45.0 \%)$ & $(4.6 \%)$ & $(2.9 \%)$ \\
& 622 & 546 & 17 & 15 \\
En los hombres las relaciones sexuales son una & $(51.8 \%)$ & $(45.5 \%)$ & $(1.4 \%)$ & $(1.3 \%)$ \\
necesidad física que no se puede controlar & 1,092 & 99 & 5 & 4 \\
Las relaciones sexuales entre personas del mismo & $(91.0 \%)$ & $(8.3 \%)$ & $(0.4 \%)$ & $(0.3 \%)$ \\
sexo son aceptables & 720 & 450 & 20 & 10 \\
El hombre es quien debe tomar la iniciativa en & $(60.6 \%)$ & $(37.5 \%)$ & $(1.7 \%)$ & $(0.9 \%)$ \\
las relaciones sexuales & 209 & 975 & 8 & 8 \\
Es normal que las mujeres tengan relaciones & $(17.4 \%)$ & $(81.3 \%)$ & $(0.7 \%)$ & $(0.7 \%)$ \\
sexuales con otros hombres, además de su pareja & 1,046 & 140 & 9 & 5 \\
Los hombres pueden tener relaciones sexuales & $(87.2 \%)$ & $(11.7 \%)$ & $(0.8 \%)$ & $(0.4 \%)$ \\
con sus parejas aunque ellas no quieran & 670 & 498 & 24 & 8 \\
Uno sólo debe pensar en tener relaciones & $(55.8 \%)$ & $(41.5 \%)$ & $(2.0 \%)$ & $(0.7 \%)$ \\
sexuales cuando va a casarse & 342 & 846 & 7 & 5 \\
Es normal que los hombres tengan relaciones & $(28.5 \%)$ & $(70.5 \%)$ & $(0.6 \%)$ & $(0.4 \%)$ \\
sexuales con otras mujeres, además de sus parejas & 369 & 796 & 22 & 13 \\
Las mujeres deben tener relaciones sexuales sólo & $(30.8 \%)$ & $(66.3 \%)$ & $(1.8 \%)$ & $(1.1 \%)$ \\
para complacer a su pareja & 566 & 611 & 19 & 4 \\
Es normal que las mujeres tengan relaciones & $(47.2 \%)$ & $(50.9 \%)$ & $(1.6 \%)$ & $(0.3 \%)$ \\
sexuales con su pareja antes del matrimonio & 536 & 562 & 71 & 31 \\
Lo más importante de la relación sexual es la & $(44.7 \%)$ & $(46.8 \%)$ & $(5.9 \%)$ & $(2.6 \%)$ \\
satisfacción personal y no tener hijos & & & & \\
\hline
\end{tabular}

Fuente: CASC-UCA -FNUAP - CEPAL. Masculinidad y Paternidad, Honduras, mayo 2002.

\section{5 Representaciones y Percepciones Sobre la Familia}

Este apartado plantea una reflexión sobre la familia como institución socializadora y lugar de intersecciones de aspiraciones, visiones, comportamientos...la vida, en el entendido que su abordaje tiene múltiples aristas por su complejidad. En ese sentido, el abordaje de este tema tiene por objeto aproximarse a las representaciones socioculturales que los hombres tienen sobre aspectos relacionados con la familia.

\section{La familia}

La familia es el ámbito donde inicialmente se conforman y modelan los modos de actuar y de pensar, es el espacio mediador entre el individuo y la sociedad, es el núcleo generador y transmisor de valores, normas y actitudes que orientan la conducta individual, para hombres y mujeres, es el primer espacio de internalización de las representaciones en torno a la identidad masculina o femenina. En este contexto, se llama la atención sobre la importancia y tras- cendencia que tiene la constitución de la familia. Dependiendo de las situaciones y relaciones familiares de los individuos, influirá en el desarrollo personal de sus miembros.

Es importante, reconocer a la familia como fenómeno social en toda su dimensión y complejidad lograda con el transcurrir del tiempo, reconocer los mitos y realidades del concepto de familia. En la creencia social y por conveniencia sociopolítica, se mantiene la idea de la familia como el espacio humano de armonía, afecto, equilibrio psicológico, seguridad en el sentido amplio y como el lugar idóneo para el desarrollo y crecimiento de la personalidad humana. Ideal de familia, que cada vez se aleja más y más de la realidad en que muchas familias se desenvuelven.

La violencia doméstica, las carencias materiales, el trabajo infantil, son manifestaciones de las formas del ejercicio del poder dentro de la familia y los sistemas de jerarquía autoritaria que dentro de ella se pueden tejer.

Lasfamilias con jefas de hogar, las familias con abuelos/as como 
cabeza de familia, las familias con padres o madres proveedores migrantes, etc. son manifestaciones de los profundos cambios que esta entidad sociocultural ha tenido. $Y$ por el peso que tiene en la sociedad como la forma primaria de socialización y pertenencia de las personas, en su análisis es importante, reconsiderarla en sus dimensiones contradictorias, y no pretender explicar a partir de casos particulares de funcionamiento aceptable socialmente, a todos los tipos de familia que se han ido conformando en la sociedad actual.

En H onduras, igual que en el resto de países de Latinoamérica, la conformación de la familia está cruzada por factores tales como: transición demográfica, desigualdades de género, altos niveles de necesidad y pobreza, recesión y exclusión social. Relaciones base en las que se mueven las personas y familias que sobreviven en inequidades de clase, género, etnia y edad.

El crecimiento de la población se corresponde con el crecimiento de unidades familiares del país a una tasa de 3.6 familias por año. La Encuesta Permanente de H ogares y Propósitos M últiples de M arzo de 1993 estimó un total de 945,811 familias y un total de población de 4,995,383, cinco años más tarde, marzo de 1998, el número había aumentado a 1,130,088 unidades familiares y un total de población de 5,783,380 habitantes (Flores Fonseca, 1999).

El verdadero fenómeno social que está detrás del incremento de familias por año, es el progresivo incremento de las unidades familiares encabezadas por mujeres solas o madres solteras, en 1996 un estudio estimaba que el $24 \%$ del total de familias del país era sostenido por una mujer, en 1998 las familias monoparentales con figura materna en $\mathrm{H}$ onduras representaban el $27.6 \%$ del total general (295,435 familias), a este dato habría que añadir la cantidad de unidades familiares que pese a tener figura paterna, son sostenidos por la contribución de la mujer-madre con la colaboración de sus hijos y/o parientes insertos en estrategias populares de sobrevivencia (Flores Fonseca, 1999).

... La familia se convirtió en experta en la tarea de socializar a los niños para que respondan a expectativas apropiadas de clase y género.

L a familia se ha ido al ejando progresivamente de las bases ideológico-religiosas que la fundamentan, "la familia como el espacio donde es permisible la unión carnal de hombres y mujeres para la procreación". Para convertirse en un espacio de sobrevivencia donde las corresponsabilidades domésticas y económicas cada vez más, quedan en manos de las mujeres, tendiendo a desaparecer la figura paterna, como el ideal del proveedor y protector de la familia y en muchos casos si se mantiene, es por la imposición arbitraria de esa imagen y no por su correspondencia a las actitudes paternas.

\section{Conformación familiar}

Disposición de recursos económicos

Época ideal para formar una familia

La institución de la familia es de mucha importancia para los hombres encuestados, no obstante, se perciben diferencias entre las representaciones de los hombres padres y los no padres, respecto a algunas proposiciones que habían sido consideradas verdades absoIutas, el pensamiento respecto a la familia como cél ula fundamental de la sociedad en los últimos tiempos ha sufrido transformaciones, asociado especialmente a factores económicos y laborales, la mayor incorporación de la mujer al trabajo y acceso a la educación.

Pese al incremento de hogares con jefatura femenina, para los hombres, la idea de una familia constituida por la pareja es importante, posiblemente los hombres hondureños aún no han percibido el fenómeno de las familias monoparental es ya que ellos en lo personal siempre estarán constituyendo una familia aunque con parejas diferentes, sin poner en consideración problemáticas como la de las madres solteras.

Prevalece un modelo de pensamiento tradicional de familia basado en la definición de roles patriarcales de la familia y sus miembros, un modelo de jerarquía masculina como eje de articulación familiar. Se observa un consenso generalizado que le da mucho valor a las relaciones familiares que considera que el principal objetivo es fundar una familia y que lo más importante para una mujer es ser madre. C omo tendencia gen eral, las respuestas de residentes rural es tienden a ser mayoritariamente favorables a proposiciones donde se afirma la primacía masculina.

La imagen de familia numerosa está fuertemente asociada a sociedades agrarias, donde la familia además de un núcleo afectivo constituye un núcleo de fuerza de trabajo, y entre más hijos se tenga más trabajadores habrá, la familia rural tiende a la permanencia de sus miembros a pesar de las edades y uniones conyugales.

Por el contrario, la idea de familia urbano-asalariada, aunque mantiene el núcleo familiar como elemento de socialización, afecto y protección, ésta sólo se tiene hasta el momento en que se está listo para constituirse en fuerza de trabajo, la función social de la familia urbana tiene un período de vida más corta que la rural. Por ello, las experiencias sociales de construcción de familia también están relacionadas a la capacidad económica de retener o no a los miembros del hogar y no sólo a los procesos afectivos y de socialización. La combinación de ellos es lo que le da consistencia a diferentes tipos de familia y las diferentes formas de pensar respecto de la familia si se es hombre o mujer, si se vive en el campo o en la ciudad, si se es joven 0 adulto.

“.... En mi vida fundar una familia no es mi prioridad, es mi segundo objetivo primordial, el ser padre y obviamente tener una familia, pero primero debo tener una profesión... un trabajo".

(Hombre no padre clase media).

En torno a las construcciones sociales de familia, permanecen valoraciones estereotipadas de las identidades construidas acerca de lo que es ser hombre y lo que es ser mujer y las relaciones con los hijos.

Se observa que la mentalidad de los hombres no es homogénea respecto a cómo se percibe la familia. $\mathrm{M}$ ientras el $71.6 \%$ está de acuerdo con que es natural que los hombres tengan hijos fuera del matrimonio, un $27.2 \%$ no está de acuerdo con esta proposición, todavía está presente la mentalidad heredada por la colonia de la existencia 
de hijos naturales y legítimos, muy ligado a aspectos materiales y jurídicos como el derecho a la herencia por parte de los hijos legítimos y el derecho a la cuarta conyugal*47 por parte de la esposa, (Rivera,Rodil, 1989).

Esta forma de pensar también tiene relación con lo que se considera el honor de las mujeres, donde además de los hijos y las hijas, son las mujeres quienes suelen salir malparadas (Paternidad irresponsable en Centroamérica: 2001).

A I respecto, en Honduras es hasta 1984 con la promulgación del $C$ ódigo de Familia que dejan de existir, auque sea formalmente, con más valor retórico que práctico las diferencias entre hijos naturales e hijos legítimos, debido a que todavía persiste en la conducta reproductiva masculina, formas de pensar que validan la existencia de los hijos de la casa y los hijos de afuera.

La mayoría de los consultados está de acuerdo en que es natural que los hombres tengan hijos fuera del matrimonio (71.6\%) y solamente el $27.3 \%$ dijo no estar de acuerdo con esa proposición. En ese sentido no es extraño encontrar opiniones como la siguiente:

".... ¿Y es que es malo pues, tener hijos por fuera?..."

( H ombre padre, clase alta, de múltiples relaciones, sector rural)

\section{Disposición de recursos económicos}

Los procesos de modernización de la sociedad, sobre todo a partir del modelo de sociedad industrial, que obliga a la incorporación masiva de las mujeres a la actividad laboral, ya sea para cubrir puestos de trabajo que las empresas necesitan o para poder solventar sus necesidades mínimas, incorporándose en el sector informal dela economía, han cambiado la situación fáctica en que se basa la ideología del hombre proveedor.

El 91.8\% de los hombres dice estar de acuerdo con que: Es mejor evitar tener hijos si no se está preparado económicamente para tenerlos, mientras el $8.8 \%$ no está de acuerdo o duda. Esta representación muestra un pensamiento propio del hombre proveedor, pero también hace alusión a los hijosque nacen de una relación de pareja estable, a los hijos de la casa. Quizá esta representación esté muy asociado a la situación socioeconómica que atraviesa el país, posiblemente ya se esté generando un pensamiento que esté dejando atrás la frase popular que dice que "cada hijo trae un pan bajo el brazo y donde comen dos, comen tres" y se tenga más conciencia de los compromisos económicos que significa tener hijos.

"... hay que tener los hijos de acuerdo a la situación económica que se tenga, para tener calidad de vida".

( H ombre padre clase media, sector urbano, de una relación)

A cerca de que si : Las parejas viven juntas sin casarse por razones económicas, una opinión dividida en de acuerdo y no de acuerdo entre padres y no padres siendo los hombres mayores de 50 años los que no están de acuerdo en un $49 \%$ con esta proposición.

Se percibe una renuencia a formar familias a través de un vínculo formal como lo es el matrimonio. Ello podría estar asociado a la incertidumbre económica, que induce a no concretar compromisos, pero también favorece que los hombres no adquieran responsabilidades ante hijos de parejas con las cuales no se han establecido vínculos conyugales.

Culturalmente, también existe la práctica de la unión libre, muy arraigada especial mente en los sectores populares y más aún de áreas rurales, establecerse como parejas sin la existencia de un vínculo legal, las conocidas uniones de hecho, tan fuerte es esta práctica en $\mathrm{H}$ onduras, que el Código de Familia de 1984 introdujo las uniones de hecho como parte de la Institución de la familia, con el propósito de velar por la protección de los derechos de los hijos nacidos de esas uniones.

\section{Época ideal para formar una familia}

A pesar que para formar una familia se requiere de una serie de atributos e implicaciones que van desde morales, educativos, de madurez y económicos, pareciera que los hombres hondureños fundamentan este evento con la posibilidad de disponer de recursos económicos. Ello se explica debido a que culturalmente los hombres han reducido su papel en la familia al de proveedores. A nte la proposición: Los hombres están preparados para formar una familia hasta que trabajan, el $76.3 \%$ se manifestó estar de acuerdo, esto es indicador de un porcentaje al to de hombres que piensan sobre la responsabilidad que significa formar una familia. Los hombres entre 16 y 19 años son los que mayoritariamente están de acuerdo con esta proposición. (80.3\%).

"... U na base económica, un trabajo y estar seguro de su responsabilidad..." (H ombre padre, sector urbano, de una sola relación, clase popular)

"... Para mi, yo digo que es tener donde vivir uno... donde llevar a la hembra a formar un hogar, eso es estar preparado".

(H ombre padre de una sola relación, sector rural, clase popular)

M ientras que el $21.3 \%$ expresó no estar de acuerdo en que: LoS hombres están preparados para formar una familia hasta que trabajan. Estas respuestas están determinadas por dos tipos de comportamiento:

- La procreación es algo natural, contra ello no se puede hacer nada.

- La previsión de los acontecimientos personales no es un hecho que culturalmente ha caracterizado a la población hondureña, no ha sido parte de la planificación nacional ni de la formación escolar, la incorporación de este hábito, por eso, es común encontrar hombres que se unen con su pareja sin haber previsto ese evento, con una actitud enajenada, en el camino se arreglan las cargas, o porque su novia o compañera quedó embarazada, además nunca se piensa en una posible separación y cual será el destino de los hijos en esos casos.

"...Pero como a veces talvez a uno le sale la oportunidad y uno dice esta no me la pierdo y talvez uno no tiene ni cama en que caer muerto, como dice el refrán, en el camino se arreglan las cargas. Esas son las consecuencias que uno sufre porque en el caso mío, cuando yo me robela 
primera mujer, 7 pesos eran los que andaba y un par de zapatos y una mudada... y ya con mujer mire, por eso creo que en ese aspecto nadie se prepara verdad?..."

(H ombre padre de múltiples parejas, clase popular, sector rural)

"...Porque la mujer le puede decir a uno llevame, yo me voy pero no la dejo, ah..., sólo queda aguantar hambre también, y uno se lleva muchos sustos, talvez ella sabe que yo no tengo nada, pero ella se decide, ... ah... porque si toda la gente pensara que yo me voy a casar con este porque tienecasa, y de que mantenerme, nadie sejuntaría, pero el amor entre la hembra y el varón son ciegos, en ese aspecto yo pienso así... Y también, si me dice: lléveme y sabe que yo tengo otra familia, yo por no desperdiciarla me la llevo, va, así como dicen el machismo,... y ya tengo otra familia".

(H ombre padre de múltiples parejas, clase popular, sector rural)

\section{Cuadro No. 5. Representaciones de los Hombres sobre la Familia}

\begin{tabular}{|c|c|c|c|c|}
\hline PROPOSICIONES & DE ACUERDO & NO DE ACUERDO & DUDO & NO SABE \\
\hline El principal objetivo es fundar una familia & $\begin{array}{l}1,124 \\
(93.7 \%)\end{array}$ & $\begin{array}{l}64 \\
(5.3 \%)\end{array}$ & $\begin{array}{l}10 \\
(0.8 \%)\end{array}$ & $\begin{array}{l}2 \\
(0.2 \%)\end{array}$ \\
\hline $\begin{array}{l}\text { Las parejas viven juntas sin casarse por razones } \\
\text { económicas }\end{array}$ & $\begin{array}{l}612 \\
(51.0 \%)\end{array}$ & $\begin{array}{l}518 \\
(43.2 \%)\end{array}$ & $\begin{array}{l}47 \\
(3.9 \%)\end{array}$ & $\begin{array}{l}23 \\
(1.9 \%)\end{array}$ \\
\hline $\begin{array}{l}\text { Los hombres están preparados para formar una } \\
\text { familia hasta que trabajan }\end{array}$ & $\begin{array}{l}916 \\
(76.3 \%)\end{array}$ & $\begin{array}{l}255 \\
(21.3 \%)\end{array}$ & $\begin{array}{l}21 \\
(1.8 \%)\end{array}$ & $\begin{array}{l}8 \\
(0.7 \%)\end{array}$ \\
\hline $\begin{array}{l}\text { Es natural que los hombres tengan hijos fuera } \\
\text { del matrimonio }\end{array}$ & $\begin{array}{l}859 \\
(71.6 \%)\end{array}$ & $\begin{array}{l}328 \\
(27.3 \%)\end{array}$ & $\begin{array}{l}10 \\
(0.8 \%)\end{array}$ & $\begin{array}{l}3 \\
(0.3 \%)\end{array}$ \\
\hline $\begin{array}{l}\text { Los hombres y las mujeres deben usar métodos } \\
\text { anticonceptivos para evitar embarazos si no se } \\
\text { desea tener un hijo }\end{array}$ & $\begin{array}{l}980 \\
(81.7 \%)\end{array}$ & $\begin{array}{l}195 \\
(16.3 \%)\end{array}$ & $\begin{array}{l}22 \\
(1.8 \%)\end{array}$ & $\begin{array}{l}3 \\
(0.3 \%)\end{array}$ \\
\hline $\begin{array}{l}\text { Es mejor evitar tener hijos si no se está preparado } \\
\text { económicamente para tenerlos }\end{array}$ & $\begin{array}{l}1,102 \\
(91.8 \%)\end{array}$ & $\begin{array}{l}84 \\
(7.0 \%)\end{array}$ & $\begin{array}{l}13 \\
(1.1 \%)\end{array}$ & $\begin{array}{l}1 \\
(0.1 \%)\end{array}$ \\
\hline $\begin{array}{l}\text { Es prioritario en la vida de un hombre tener una } \\
\text { casa, un carro una moto }\end{array}$ & $\begin{array}{l}998 \\
(83.2 \%)\end{array}$ & $\begin{array}{l}174 \\
(14.5 \%)\end{array}$ & $\begin{array}{l}25 \\
(2.1 \%)\end{array}$ & $\begin{array}{l}3 \\
(0.3 \%)\end{array}$ \\
\hline $\begin{array}{l}\text { Independiente de los problemas económicos } \\
\text { que se tengan hay que apoyar y cuidar siempre a los hijos }\end{array}$ & $\begin{array}{l}1,167 \\
(97.3 \%)\end{array}$ & $\begin{array}{l}18 \\
(1.5 \%)\end{array}$ & $\begin{array}{l}14 \\
(1.2 \%)\end{array}$ & $\begin{array}{l}1 \\
(0.1 \%)\end{array}$ \\
\hline Lo más importante en la vida es la familia & $\begin{array}{l}1,165 \\
(97.1 \%)\end{array}$ & $\begin{array}{l}29 \\
(2.4 \%)\end{array}$ & $\begin{array}{l}6 \\
(0.5 \%)\end{array}$ & $\begin{array}{l}0 \\
(0.0 \%)\end{array}$ \\
\hline Lo más importante para una mujer es ser madre & $\begin{array}{l}909 \\
(75.8 \%)\end{array}$ & $\begin{array}{l}153 \\
(12.8 \%)\end{array}$ & $\begin{array}{l}76 \\
(6.3 \%)\end{array}$ & $\begin{array}{l}62 \\
(5.2 \%)\end{array}$ \\
\hline
\end{tabular}

Fuente: CASC-UCA -FNUAP - CEPAL. Masculinidad y Paternidad, Honduras, mayo 2002. 


\subsection{Representaciones y Percepciones Sobre la Masculinidad}

El análisis de los simbolismos de género en una cultura permite comprender la forma en que se conocen y representan los géneros, sus relaciones y las identidades. La masculinidad existe como simbolismo, como ideología y como conducta codificada. A I igual que la femineidad, la masculinidad es una construcción cultural relacionada con el sexo biológico pero no determinada por éste.

\section{Poder: símbolo de superioridad masculina}

M arques y 0 sborne 1991, al referirse al proceso de construcción social del varón, afirman que: este proceso es uniformador de los varones y a su vez aumenta las diferencias entre hombres y mujeres. Entre los hábitos propios de los varones, muchos traducen una perspectiva desde lo alto de la jerarquía social o constituyen modos propios de quien manda, aunque sólo sea sobre una mujer y unos niños. El gusto por la demostración o simulación de la fuerza y el poder pertenecen a este tipo.

Foucoult por su parte refiere que las relaciones de poder están profundamente arraigadas en todo el tejido social y no se agotan en el ámbito público o del Estado, otras relaciones como las relaciones entre géneros, entre las razas, etc. determinan las formas de poder existentes en una sociedad y estructuran la identidad de las acciones en los individuos y los sujetos colectivos.

Pese a que la mayoría de la producción teórica hace referencia a un proceso uniformador del varón, en esta investigación al aplicar el análisis factorial de correspondencias múltiples, se encontró que entre los varones hondureños existen diferentes formas de concebir el ser hombre. Sin embargo, prevalece el pensamiento tradicional jerárquico.

El planteamiento anterior se valida con las respuestas que los hombres dieron a las proposiciones: El hombre debe ser siempre el jefe del hogar, el $87.4 \%$ está de acuerdo y solamente el $11.5 \%$ no, los que dudan o los que no saben representan $0.8 \%$ y $0.4 \%$ respectivamente.

Estas representaciones son características de la familia hondureña, el pensamiento jerárquico hace referencia a la consigna básica transmitida al varón que "ser varón es ser importante", por lo que adquiere los hábitos de al guien que manda, (Tábora, Rocío: 1995). La sociedad hondureña se debate contradictoriamente entre incorporar los valores modernos que impone el desarrollo humano o conservar las características de una cultura tradicional.

... Porque el hombre es la cabeza del hogar, ... La mujer tiene igual derecho de tomar decisiones, pero tiene que llevar más uno, si más uno.... Porque como ya dije, el hombre es la cabeza del hogar...

( $H$ ombre padre, clase popular, sector rural)

Como se dijo anteriormente, las diferencias que se dan en la socialización entre hombres y mujeres tiene repercusiones negativas, tanto en el ámbito público como privado, marca diferencias entre ambos.

En la familia tradicional hondureña con frecuencia se desvaloriza las actuaciones de la mujer, limitándola en sus posibilidades de crecimiento como humana. 0 tro problema que se asocia a esta forma de mentalidad es el enfrentamiento que se da entre padres e hijos/as, cuando el padre impone sus ideas autoritariamente y la madre no está de acuerdo, se produce un círculo vicioso de reproducción de los mismos patrones de comportamiento paterno. La mayoría (76.8\%) de los consultados estuvieron de acuerdo en que: $C$ uando se toman las decisiones es el hombre quien debe tomar la última palabra. Sin embargo, aunque en menor proporción, hay hombres que no están de acuerdo con ello. Esta manera de pensar se puede encontrar en los hombres de diferentes estratos sociales y áreas de residencia, sin embargo, esta mental idad general mente es representativa de los hombres con procedencia del medio rural o que pertenecen al sector popular.

"... Las decisiones en un hogar las debe tomar uno, las mujer también toma ciertas decisiones, pero son más valiosas las del hombre..."

( $H$ ombre no padre, clase popular, sector rural)

"... Tengo mis responsabilidades como hombre de la casa proveedor, pero también tengo a mi esposa que me auxilia con esa autoridad y ella es una extensión de mi autoridad en la casa cuando yo no estoy..."

( $H$ ombre padre clase media, sector urbano)

La sociedad hondureña está envuelta en una disyun tiva crucial, un largo pasado construido con las jerarquías autoritarias y violentas no sólo de lo público sino también en las relaciones privadas y una sociedad, principalmente joven, que visualiza relaciones diferentes entre hombres y mujeres, entre padres e hijos, entre hermanos mayores y menores, entre jóvenes y adultos.

Para los hombres de clase media: La comodidad de ser el "hombre de la casa, el que lleva los pantalones", se complica con las enormes exigencias materiales: la casa, la comida, la escuela, la ropa, la recreación, en un ambiente económico de crisis generalizada, con problemas de empleo o calidad de empleo.

Para los hombres de clases populares: el conflicto de no poder demostrar que se es el hombre de la casa, el que lleva los pantalones, porque las mujeres y los hijos, igualmente los llevan al tener que cubrir jornadas de trabajo tan extensas o más como las de ellos mismos.

Las ideas inculcadas por las progenitorasy progenitores, las ideas de los amigos y parientes, que ya no encuentran mucha coincidencia con los comportamientos de mujeres y jóvenes que buscan otro tipo de oportunidades y posibilidades, constituyen un momento especial para la sociedad hondureña. Se da paso a nuevas formas de pensar y organizar la sociedad para que las cargas materiales y emocionales individuales no sean tan pesadas y se alivien del riesgo del no va más. 0 retrocedemos a una situación de violencia exacerbada contra las mujeres, jóvenes, niños y niñas, como la posibilidad de los hombres de defender sus privilegios.

\section{Representación de lo masculino y lo femenino}

En las representaciones que se tienen de lo masculino y lo femenino, llorar es de mujeres, es femenino, y lo femenino ha sido 
exaltado como símbolo de debilidad y los hombres son fuertes, valientes, firmes, heroicos, viriles. Culturalmente se les tiene negada la posi bilidad de expresar sus sentimientos. Sin embargo, Ias diferencias entre hombres y mujeres son construcciones cultural es desde la sociedad, nada es genéticamente femenino ni genéticamente masculino.

Ello genera en los hombres limitaciones en sus manifestaciones afectivas personal es y filiales, una carga del sistema. N o obstante, la mayoría de los consultados (68.0\%) no está de acuerdo con la proposición los hombres no lloran porque llorar es de mujeres y una opinión dividida respecto a que el hombre no debe expresar sus sentimientos y su ternura, 50\% está de acuerdo, 48.7\% no. Los hombres ya se están dando cuenta el peso emocional que conlleva para ellos negarse la posibilidad de manifestar sus sentimientos.

A unque la masculinidad está definida a partir de estereotipos androcéntricos, en las respuestas de los informantes ya se pone de manifiesto algunas fisuras del discurso a favor de la figura "hombre fuerte", un $48.5 \%$ de hombres residentes en áreas urbanas y $48.8 \%$ de residentes rurales no están de acuerdo en que EI hombre no debe expresar sus sentimientos ni su ternura. $72.1 \%$ de residentes urbanos y $64 \%$ de residentes rural es no están de acuerdo en que los hombres no lloran porque llorar es de mujeres. M ayoritariamente (más del 80\%) está aceptando que La mujer tiene el mismo derecho que el hombre de trabajar fuera de casa y de estudiar.

O tra manifestación de cambio aunque incipiente probablemente influenciado por las dificultades económicas imperantes se encuentra en las respuestas a las proposiciones: El aporte de dinero que puede hacer la mujer que trabaja fuera de la casa no compensa el daño por su desatención al hogar, un $43.3 \%$ de los hombres padres y un $44.2 \%$ de los hombres no padres no está de acuerdo. Sin embargo, siguen presentándose mayoritariamente las opiniones que reafirman el dominio masculino.

Este relativo debilitamiento de la imagen del ser hombre fuerte, sin derecho a la debilidad, ha sido posible gracias a las luchas de las mujeres por cambiar las relaciones sociales entre hombres y mujeres, el reclamo del derecho a la opción sexual de los homosexuales, la incorporación masiva de las mujeres a la vida pública (trabajo, estudios), los derechos humanos conquistados para los jóvenes y los cambios social es que exige la estructura económica actual ( sociedadesmenosinhibidas, mayor agresividad, competitividad, asumir riesgos, etc.), son parte de las condicionantes que están presionando por cambios sustancial es de comportamiento no sólo de los hombres sino de las mujeres.

M anejar la imagen, demostrar capacidad pero también ser compasivo, son valores que están imponiendo las nuevas relaciones laborales mundiales. La imagen ideal del ejecutivo de los grandes consorcios, es el modelo masculino que la nueva sociedad impone, imagen que aunque recupera y se basa en el poder que detentan loshombres en la sociedad, ya no es el macho, desarreglado, maleducado, maloliente, al estilo de las películas mexicanas de la primera mitad del siglo pasado.

De alguna forma, estos cambios y sobre todo nuevas imágenes proyectadas mundialmente por los medios de comunicación, están permeando las representaciones estereotipadas de lo femenino y lo masculino.

\section{Desigualdad a partir del género}

A pesar de la existencia de leyes que declaren la igual dad entre Ios/as ciudadano/as, la realidad indica lo contrario. Los hombres y las mujeres para unas cosas son igual es y para otras men os iguales. En las relaciones entre hombres y mujeres la inclusión y la exclusión coexisten cotidianamente.

C uando se trata de valorar la infidelidad en la pareja, el control social ubica a las mujeres en situación de desigual dad. U n comportamiento que históricamente ha sido masculino y además dispensado por la familia, por la sociedad y hasta por las leyes, y que propicia la desintegración familiar y la existencia de numerosos hijos sin padre; para el mismo hecho, culpabiliza más a las mujeres que a los hombres. M ás de la mitad de los consultados (66.7\%), estuvo de acuerdo en quela infidelidad matrimonial esmás grave en la mujer que en el hombre, mientras que el $30.6 \%$ no.

Fue hasta con la promulgación del Nuevo Código Penal en 1988 que deja de considerarse como atenuante la infidelidad de la mujer, cuando el hombre la ha asesinado. U na lucha fuerte libraron losmovimientos de mujeres para eliminar ese articulado en el nuevo Código Penal. Ha sido una petición constante de los movimientos de mujeres posibilitar la incorporación en condiciones de igualdad de las mujeres a la vida pública, en el año 2000 mediante decreto N o. 34, del Congreso N acional se promulgó la Ley de Igualdad de 0 portunidades, un avance significativo en pro de la eliminación de las relaciones desiguales.

N o obstante, el peso de los patrones culturales se pone de manifiesto cotidianamente un pensamiento dividido se encuentra en los hombres entrevistados cuan do se trata de opinar sobre si la mujer debe 0 no participar en reuniones políticas o sociales porque desatiende a los hijos, el $47 \%$ se manifiesta de acuerdo en que no debe participar, el $49.0 \%$ no está de acuerdo y $3.8 \%$ los que dudan y no saben.

En H onduras de acuerdo a la Ley de Igualdad de O portunidades el 30\% de cargos públicos y en partidos políticos deben estar ocupados por mujeres. A pesar de los avances en el marco jurídico, mismos que han ayudado a visibilizar las situaciones de desventaja social de la mujer, todavía no se cuenta con un control social que ayude a las mujeres a posicionarse en igualdad de condiciones en el ámbito público y el privado.

Respecto a la proposición la mujer tiene el mismo derecho de trabajar fuera de casa y de estudiar, la mayoría contestó estar de acuerdo y solamente un $11.3 \%$ no, en menor proporción los que dudan y 
no saben. Probablemente las dificultades económicas imperantes hayan obligado a los hombres a cambiar de mentalidad. Las mujeres han tenido que incorporarse masivamente al trabajo para contribuir a solventar la sobrevivencia familiar, especialmente las madres solteras jefas de hogar. Según la Encuesta Permanente de Hogares y Propósitos M últiples, 2001, las mujeres representan el $35.7 \%$ de la población económicamente activa, con un $36 \%$ de tasa de participación laboral.

N o obstante que las mujeres han demostrado su potencial de participación económica y social, la incorporación masiva de las mujeres como fuerza de trabajo, en muchos casos ha significado caer en el fenómeno de la feminización de la pobreza, hoy en día las mujeres trabajan más para ganar menos, y no siempre los nivel es educativos alcanzados se corresponden con los niveles salarial es. Según la Encuesta de Hogares y Propósitos M últiples del 2001, el 51.7\% de laspersonas que está en el quintil más bajo de ingresos, son mujeres.

En los últimos años la población hondureña se ha visto expuesta a un deterioro de la calidad de vida debido a múltiples factores: falta de fuentes de trabajo, el evadas tasas de desempleo, deterioro de la economía, incremento de la criminalidad, etc. U na de las consecuencias de este deterioro es que las personas tienen poca disponibilidad de recursos económicos.

En los hombresse percibe un conflicto interno entre mantener los patrones culturales o adaptarse a los cambios de la vida moderna, especialmente lo relacionado con la situación económica y el mantenimiento del hogar. Los hallazgos de esta investigación demuestran que el pensamiento tradicional de los hombres prevalece. A nte la proposición el hombre es el único que debe mantener el hogar, el $72.1 \%$ dijo estar de acuerdo y solamente el $27.3 \%$ no.

". . ¿. Q uién debe trabajar en el hogar?... pues ahorita por cuestiones de simbología social, es el hombre. Pero mi esposa... ella trabaja también. Son trabajos no fijos y lo hemos hablado, lo hemos discutido. Inicialmente siento que le corresponde al hombre, proveer y quien le da buen manejo a todo ese dinero es la esposa...."

(Hombre padre clase media, de una relación)

“...L a mujer debe trabajar... Si claro, porque en A mérica Latina no basta con un salario, tiene que haber dos trabajando, el padre y la madre sin descuidar sus hijos y el hogar".

( $H$ ombre padre clase media, sector urbano)

La masculinidad, es una construcción derivada de las características que naturalmente diferencian a los hombres de las mujeres, pero además está acompañada de todas las construcciones sociales que se le han adherido provenientes de lo moral, lo ético, las costumbres y creencias.: En la vida el hombre representa la inteligencia y la fuerza, cuando se toman decisiones el hombre es quien debe tener la última palabra, el hombre es el único responsable de mantener el hogar, el hombre debe ser siempre el jefe del hogar, el hombre no debe de expresar su sentimiento ni su ternura, los hombres no lloran porque llorar es de muje- res, las mujeres son más pacíficas que los hombres, la mujer no debe participar en actividades políticas y sociales porque desatiende a sus hijos, el aporte de dinero que puede hacer la mujer que trabaja no compensa el daño que causa por su desatención al hogar, si el hombre tiene suficientes ingresos la mujer no debe trabajar, la infidelidad matrimonial es más grave en la mujer que en el hombre, tener un hijo es muestra de que se es hombre, los padres prefieren al hijo varón porque garantiza mantener el apellido. Este conjunto de proposiciones aceptadas ampliamente por los entrevistados, en primer lugar reproducen la imagen estereotipada del hombre fuerte, la mujer débil, el hombre actuando en el ámbito público y la mujer en el privado, el hombre proveedor-productivo, la mujer reproductora, etc., y en segundo lugar, la reproducción de un pensamiento conservador que poco ha evolucionado en términos de las relaciones de género y los nuevos patrones sociales y de derechos humanos basados en la equidad.

La masculinidad androcéntrica está fuertemente arraigada entre la población hondureña, sin embargo, los valores sobre la supremacía masculina no sólo han afectado a la mujer por su desval orización, pérdida de derechos y autonomía, sino que ya hay manifestaciones de cómo ha afectado a los hombres, principalmente por la pérdida del derecho a la afectividad. Ello abre la posibilidad de recuperar la construcción social de la masculinidad y por lo tanto sujeta a cambios que no necesariamente significan la pérdida o renuncia a la sexualidad masculina.

Este modelo de pensamiento reafirma la condición histórica de la construcción de masculinidad y la probabilidad del cambio de mentalidades. Pero también pone en evidencia que algunos hombres ya no están satisfechos con un rol estereotipado de masculinidad que la sociedad les ha impuesto.

Quizá este sea el hallazgo más importante, la posibilidad de manifestar que no se está totalmente de acuerdo con un patrón cultural que ha dejado atrapado al hombre y a la sociedad, en un esquema sin derecho a los sentimientos y la afectividad, ya que las mujeres pueden mostrar su sentimiento por ser mujeres, por ser débiles, no por una necesidad humana, que al igual que los hombres, por ser fuertes no pueden expresar sus necesidades humanas.

La influencia judeocristiana es un factor determinante en la reducción de la sexualidad a las relaciones coitales cuyo propósito último esla procreación. A I reducir la sexualidad a relaciones sexuales coitales, se han dejado por fuera otros aspectos de la sexualidad que incluyen las expresiones corporales, la afectividad, las manifestaciones de cariño, las caricias, que puedan ser manifestadas entre hombres y mujeres y entre los mismos sexos sin que ello signifique homosexualidad, debilidad de carácter, etc. R ecuperar la afectividad y emotividad como parte de la sexualidad propia de los seres humanos, puede estar significan do uno de los cambios social es importantes de la humanidad. 
Cuadro No. 6. Representaciones de los Hombres Sobre la Masculinidad

\begin{tabular}{|c|c|c|c|c|}
\hline PROPOSICIONES & DE ACUERDO & NO DE ACUERDO & DUDO & NO SABE \\
\hline $\begin{array}{l}\text { Si una mujer engaña al hombre, él puede } \\
\text { castigarla }\end{array}$ & $\begin{array}{l}338 \\
(28.2 \%)\end{array}$ & $\begin{array}{l}829 \\
(69.1 \%)\end{array}$ & $\begin{array}{l}20 \\
(1.7 \%)\end{array}$ & $\begin{array}{l}13 \\
(1.1 \%)\end{array}$ \\
\hline La mujer no debe participar en reuniones políticas & 566 & 588 & 26 & 19 \\
\hline $\begin{array}{l}\text { o sociales porque desatiende a los hijos } \\
\text { El hombre debe ayudar a la mujer en las labores } \\
\text { domésticas }\end{array}$ & $\begin{array}{l}(47.2 \%) \\
1,143 \\
(95.3 \%)\end{array}$ & $\begin{array}{l}(49.0 \%) \\
49 \\
(4.1 \%)\end{array}$ & $\begin{array}{l}(2.2 \%) \\
5 \\
(0.4 \%)\end{array}$ & $\begin{array}{l}(1.6 \%) \\
3 \\
(0.3 \%)\end{array}$ \\
\hline Las mujeres son más pacíficas que los hombres & $\begin{array}{l}743 \\
(61.9 \%)\end{array}$ & $\begin{array}{l}305 \\
(25.4 \%)\end{array}$ & $\begin{array}{l}138 \\
(11.5 \%)\end{array}$ & $\begin{array}{l}14 \\
(1.2 \%)\end{array}$ \\
\hline $\begin{array}{l}\text { El aporte de dinero que puede hacer la mujer } \\
\text { que trabaja fuera de la casa no compensa el daño } \\
\text { que causa por su desatención al hogar }\end{array}$ & $\begin{array}{l}550 \\
(45.8 \%)\end{array}$ & $\begin{array}{l}525 \\
(43.8 \%)\end{array}$ & $\begin{array}{l}84 \\
(7.0 \%)\end{array}$ & $\begin{array}{l}41 \\
(3.4 \%)\end{array}$ \\
\hline $\begin{array}{l}\text { El hombre no debe expresar sus sentimientos } \\
\text { ni su ternura }\end{array}$ & $\begin{array}{l}600 \\
(50.0 \%)\end{array}$ & $\begin{array}{l}584 \\
(48.7 \%)\end{array}$ & $\begin{array}{l}10 \\
(0.8 \%)\end{array}$ & $\begin{array}{l}6 \\
(0.5 \%)\end{array}$ \\
\hline $\begin{array}{l}\text { Si el hombre tiene suficientes ingresos la mujer } \\
\text { no debe trabajar }\end{array}$ & $\begin{array}{l}825 \\
(68.9 \%)\end{array}$ & $\begin{array}{l}347 \\
(28.9 \%)\end{array}$ & $\begin{array}{l}17 \\
(1.4 \%)\end{array}$ & $\begin{array}{l}9 \\
(0.8 \%)\end{array}$ \\
\hline $\begin{array}{l}\text { La infidelidad matrimonial es más grave en la } \\
\text { mujer que en el hombre }\end{array}$ & $\begin{array}{l}800 \\
(66.7 \%)\end{array}$ & $\begin{array}{l}367 \\
(30.6 \%)\end{array}$ & $\begin{array}{l}20 \\
(1.7 \%)\end{array}$ & $\begin{array}{l}13 \\
(1.1 \%)\end{array}$ \\
\hline El hombre debe ser siempre el jefe del hogar & $\begin{array}{l}1,049 \\
(87.4 \%)\end{array}$ & $\begin{array}{l}138 \\
(11.5 \%)\end{array}$ & $\begin{array}{l}9 \\
(0.8 \%)\end{array}$ & $\begin{array}{l}4 \\
(0.4 \%)\end{array}$ \\
\hline $\begin{array}{l}\text { La mujer tiene el mismo derecho que el hombre } \\
\text { de trabajar fuera de casa y de estudiar }\end{array}$ & $\begin{array}{l}1,050 \\
(87.5 \%)\end{array}$ & $\begin{array}{l}136 \\
(11.3 \%)\end{array}$ & $\begin{array}{l}13 \\
(1.1 \%)\end{array}$ & $\begin{array}{l}1 \\
(0.1 \%)\end{array}$ \\
\hline Los hombres no lloran porque llorar es de mujeres & $\begin{array}{l}372 \\
(31.0 \%)\end{array}$ & $\begin{array}{l}816 \\
(68.0 \%)\end{array}$ & $\begin{array}{l}9 \\
(0.8 \%)\end{array}$ & $\begin{array}{l}3 \\
(0.3 \%)\end{array}$ \\
\hline $\begin{array}{l}\text { El hombre es el único responsable de mantener } \\
\text { el hogar }\end{array}$ & $\begin{array}{l}865 \\
(72.1 \%)\end{array}$ & $\begin{array}{l}327 \\
(27.3 \%)\end{array}$ & $\begin{array}{l}5 \\
(0.4 \%)\end{array}$ & $\begin{array}{l}3 \\
(0.3 \%)\end{array}$ \\
\hline $\begin{array}{l}\text { El hombre representa la inteligencia y la fuerza } \\
\text { en la vida y la mujer el amor y la debilidad }\end{array}$ & $\begin{array}{l}898 \\
(74.8 \%)\end{array}$ & $\begin{array}{l}260 \\
(21.7 \%)\end{array}$ & $\begin{array}{l}28 \\
(2.3 \%)\end{array}$ & $\begin{array}{l}14 \\
(1.2 \%)\end{array}$ \\
\hline $\begin{array}{l}\text { Cuando se toman decisiones el hombre es quien } \\
\text { debe tener la última palabra }\end{array}$ & $\begin{array}{l}921 \\
(76.8 \%)\end{array}$ & $\begin{array}{l}256 \\
(21.3 \%)\end{array}$ & $\begin{array}{l}16 \\
(1.3 \%)\end{array}$ & $\begin{array}{l}7 \\
(0.6 \%)\end{array}$ \\
\hline
\end{tabular}

Fuente: CASC-UCA -FNUAP - CEPAL. Masculinidad y Paternidad, Honduras, mayo 2002.

\subsection{Perfiles de la Visión de Masculinidad de los H ombres}

Dela aplicación del análisisfactorial de correspondencias múltiples al resultado de las encuestas en el apartado correspondiente a la masculinidad, resultaron tres perfiles o ti pologías de pen samiento: perfil de pensamiento de masculinidad tradicional androcéntrica, perfil de pensamiento hacia la igual dad de géneros y perfil de pensamiento en transición.

\section{Perfil de pensamiento de masculinidad tradicional androcéntrica}

Este primer grupo incluye al mayor número de hombres encuestados (60.5\%). Esta visión de la masculinidad está determinada por respuestas afirmativas a un conjunto de proposiciones que hacen referencia a estereotipos conservadores de género basados en la concepción androcéntrica del mundo.

Este perfil de pensamiento aparece asociado a encuestados que poseen un bajo nivel educativo que apenas alcanza el nivel primario o que son analfabetos y que poseen un empleo temporal. $\mathrm{N}$ o se asocia la variable sector de residencia, lo que indica que el pensamiento tradicional tan arraigado en la sociedad hondureña se encuentra tanto en los hombres que habitan el medio rural como el urbano.

Este perfil de hombres estaría explicando su masculinidad a partir de consideraciones androcéntricas de orden jerárquico.

\section{Perfil de pensamiento hacia la igualdad de géneros}

El perfil de pensamiento hacia la igualdad de géneros, es porcentualmente menor, está determinado por el $22.25 \%$ de respuestas en desacuerdo a proposiciones que refieren a estereotipos de 
género conservadores. L os hombres que se encuentran en este grupo son los que estarían rompiendo con los estereotipos de una masculinidad androcéntrica.

A parece asociado a encuestados que poseen nivel educativo medio y superior, con residencia en el área urbana y que se encuentran casados

\section{Perfil de pensamiento en transición}

El perfil de pensamiento en tránsito está determinado por el $17.25 \%$ de respuestas de duda y de acuerdo a proposiciones conservadoras.

Este constituye el típico modelo de pensamiento que sufre un proceso de transición, de la realidad obtiene representaciones que ya no coinciden con sus creencias y costumbres, sin embargo, la fuerza del medio social hace que se mantengan creencias que cada vez más se al ejan de la realidad fáctica de cómo actúan las mujeres y los hombres en al gunas esferas de la cotidianeidad.

Los hombresque están poniendo en duda el model o de masculinidad androcéntrica no poseen características personales específicas de peso que determinen su forma de pensar, ello hace suponer que es muy amplio el espectro de posibilidades para profundizar perfiles de masculinidad no tradicional.

\subsection{Representaciones y Percepciones Sobre la Sexualidad y la Reproducción}

En la tradición judeocristiana la sexual idad se ha asociado muy estrechamente a la reproducción, generando el estereotipo de que las relaciones sexuales sólo se justifican por ésta. A la mujer no se le permite el placer sexual y al hombre por su naturaleza se le indica que con la esposa se debe tener hijos y para obtener placer puede buscar otro tipo de mujeres.

\section{Reproducción versus responsabilidades femeninas o masculi- nas}

Bajo los preceptos anteriores es razonable encontrar dos formas de pensamiento contradictorios a partir de las respuestas de los hombres, en cuanto a estar de acuerdo (77.3\%) en que es asunto de las mujeres cuidarse para no quedar embarazadas, y no estar de acuerdo $(58.0 \%)$ en que la mujer puede evitar los hijos sin el permiso de los hombres. A partir de esta mentalidad existen percepciones de responsabilidades diferentesen el proceso de toma de decisiones reproductivas, los hombres el placer y las mujeres la responsabilidad. Cuando se trata de tomar medidas de prevención la responsabilidad es de la mujer, pero cuando se trata de tomar decisiones, la responsabilidad es del hombre.

Las mujeres madres participantes a un grupo focal en el área rural comentaron que sus compañeros o esposos cuando ellas les dicen que creen estar embarazadas porque no les viene la menstruación, ellos se enojan y las cul pabilizan por no haberse cuidado, transfiriéndoles la responsabilidad del nuevo hijo.

En ese sentido el pensamiento sobre la reproducción, está determinado por la construcción machista de la sexualidad: Es asunto de la mujer el cuidarse para no quedar embarazada, la infidelidad matrimonial es más grave en la mujer que en el hombre, los hombres están preparados para formar una familia hasta que trabajan, el aporte de dinero que puede hacer la mujer que trabaja fuera de la casa no compensa el daño que causa por su desatención al hogar, si el hombre tiene suficientes ingresos la mujer no debe trabajar.

A firmaciones que permiten discernir entre las responsabilidades masculinas y femeninas frente a la reproducción, que desde la perspectiva de los hombres, la reproducción es responsabilidad de la mujer, ella debe hacer y comportarse de acuerdo a un patrón de madre, ellos, deben asumir el papel de proveedores. De acuerdo a la visión tradicional de los hombres entrevistados, el papel de proveedor es quizá la única responsabilidad del hombre frente a la reproducción.

Con la proposición es la pareja quien debe decidir si quiere tener un hijo o no, sobre la que manifiestan estar de acuerdo el $92.9 \%$ y solamente $6.8 \%$ no, puede constituir una manifestación de que las mujeres por sí mismas no pueden decidir acerca de la maternidad.

Es claro que la encuesta y los testimonios traslucen un sentido de responsabilidad por parte de los hombres encuestados, pero también de doble discurso ante una realidad que se presenta diferente ante un actuar predominantemente machista y en donde sexualidad y reproducción se confunden.

"... Si... fue discutido, como novios fue discutido bastante, como esposos fue dialogado y planificado eficientemente".

(H ombre padre de una sola relación, clase media, sector urbano)

El tener un hijo es la mejor prueba de amor de la mujer hacia el hombre, el $69.9 \%$ de los consultados está de acuerdo y $26.7 \%$ no, muy pocos están dudando o no saben. U na manifestación de amor de la mujer hacia el hombre en las relaciones de pareja es la procreación, por ejemplo, en la frase popular: "a ese hombre le voy a dar un hijo porque lo amo", se pone de manifiesto la confusión que existe en los hombres y las mujeres entre sexualidad y reproducción, y más que confusión la utilización de los hijos como mecanismo de retención en las relaciones sentimentales. 0 tro problema que se genera a partir de esa representación, es que no todos los hombres están de acuerdo en recibir esa prueba de amor y como siempre debido a la desigualdad en las parejas los(as) perjudicados son los hijos y las madres.

"Yo decidí, tener a Sarah, pensando que mi marido se iba a quedar conmigo, para que no se fuera.....y de todas maneras se fue..."

( $C$ omentario surgido en un grupo focal con mujeres ruralesl)

“....E Ella salió embarazada porque se sentía ya con los deseos de demostrar su capacidad como madre y sentirse realizada y comprometida conmigo, porque también quería darme la satisfacción de darme un varón".

(H ombre padre clase media, sector urbano)

En general las opiniones tienden a favorecer un pensamiento tradicional androcéntrico, sin embargo, se advierten algunas diferencias significativas entre hombres residentes urbanos y rurales. 
Cuadro No. 7 Representaciones de los Hombres sobre la Reproducción

\begin{tabular}{|lllll|}
\hline PROPOSICIONES & DE ACUERDO & NO DE ACUERDO & DUDO & NO SABE \\
\hline Es la pareja quien debe decidir si quiere tener & 1,115 & 74 & 9 & 1 \\
un hijo o no & $(92.9 \%)$ & $(6.2 \%)$ & $(0.8 \%)$ & $(0.1 \%)$ \\
Es asunto de la mujer cuidarse para no quedar & 928 & 262 & 6 & 4 \\
embarazada & $(77.3 \%)$ & $(21.8 \%)$ & $(0.5 \%)$ & $(0.3 \%)$ \\
La mujer puede evitar los hijos sin el permiso & 481 & 696 & 16 & 7 \\
del hombre & $(40.1 \%)$ & $(58.0 \%)$ & $(1.3 \%)$ & $(0.6 \%)$ \\
El tener un hijo es la mejor prueba de amor & 839 & 320 & 32 & 9 \\
de la mujer hacia el hombre & $(69.9 \%)$ & $(26.7 \%)$ & $(2.7 \%)$ & $(0.8 \%)$ \\
\hline
\end{tabular}

Fuente: Encuesta CASC-UCA -FNUAP - CEPAL. Masculinidad y Paternidad, Honduras, mayo 2002. 2002

\section{El embarazo sin planificación}

Los hombres participantes a un grupo focal perciben de diferentesformas el hecho de un eventual embarazo en sus parejas, mientras para unos, dependiendo del grado de formalidad que exista en la pareja así será asumido o no el embarazo, para otros en la venida de un hijo siempre debe responsabilizarse el padre aunque no continúe la relación, porque como dijo un participante al grupo focal si sucede que le apriete la guacha porque siempre hay formas de prevención.

“... Yo no podría aceptar y es más creer que un hijo es mío si sólo me he acostado con una chava una vez, y que tal que después salga diciendo que está embarazada...."

(H ombre no padre, sector popular, área urbana)

\section{Conocimiento de métodos anticonceptivos}

La anticoncepción constituye un factor importante del comportamiento reproductivo en cuanto que influye significativamente en cierto nivel de fecundidad. A partir del conocimiento de los métodos anticonceptivos se generan en hombres y mujeres expectativas y representaciones social es diferentes, es en la cotidianeidad donde se trasmiten estos significados. La mayoría de los entrevistados conoce los diferentes métodos anticonceptivos, siendo los predominantes el condón (88.3\%) y la píldora (65.7\%). El condón es quizá, el método más promocionado y el que goza de mayor popularidad en los hombres, especialmente a partir del aparecimiento del SIDA por su doble función, protección para prevenir el contagio de enfermedades de transmisión sexual y ser un contraceptivo; está disponible en instituciones públicas del Estado y en establecimientos comerciales, sin embargo, existe una campaña permanente por parte de las iglesias especialmente la católica y de las organizaciones pro vida para contrarrestar el uso del condón en la población masculina, aduciendo que su uso lleva a la pérdida de los valores moral es y contraviene el mandato de Dios.

Los métodos menos conocidos por los hombres son: la esterilización quirúrgica (13.5\%) y el ritmo (19.6\%). En el caso de la esterilización quirúrgica posiblemente el desconocimiento se deba a que la promoción de la misma no se hace en forma masiva, probablemente influyen varios factores: altos costos, requiere de una cirugía que hace necesario un ingreso hospitalario, a nivel nacional las unidades prestadoras de servicios de salud con capacidad para asistir cirugías es limitado, temor a perder la vida pese a que es una cirugía menor con poco riesgos, mitos en la población masculina y femenina respecto a perder virilidad en los hombres y el placer en la relación sexual en las mujeres. $Y$ en el caso del ritmo, no obstante ser un método anticonceptivo sin costo económico, no ha sido promocionado con la misma intensidad que los otros, ya que para lograr su eficacia es necesario un cambio en los patrones culturales, una mayor educación, disciplina y conocimiento de las funciones biológicas del cuerpo de las mujeres, así como de una relación de respeto y entendimiento mutuo entre la pareja en cuanto a las fechas en que se pueden tener relaciones sexuales y las que no. Difícil de lograr en una sociedad con patrones culturales de relaciones sexuales hegemónicas en donde el hombre casi nunca admite concesiones en los momentos que decide tener placer sexual.

La mayoría de los entrevistados conoce los diferentes métodos de planificación, siendo los predominantes el condón y la píldora. Con todo, las prácticas anticonceptivas institucionalizadas han Iogrado penetrar en las estructuras culturales, por lo menos en un nivel de discurso.

\section{Fuente de conocimiento de métodos de planificación}

H oy día la promoción del uso de los métodos anticonceptivos pasa por una censura por parte de la I glesia C atólica y de organismo pro vida, critican la publicidad que se hace sobre el uso de estos métodos, especialmente el preservativo, se debaten en un cuestionamiento ético y moral sobre la procreación, limitando en cierta medida la libertad de las parejas de decidir, regular y administrar su fecundidad.

En la educación de los padres hacia los hijos e hijas la anticoncepción no ha sido una temática de abordaje familiar, ha sido considerado un tabú a partir del cual se crean diferentes signifi- 
cados y representaciones, en al gunos casos por desconocimiento de los mismos padres y en otros porque se piensa que hablarle a los hijos de métodos de planificación es hacerles una invitación a la iniciación temprana de las relaciones sexuales, otros lo ven como símbolo de irrespeto.

El espacio por excelencia para abordar los temas relacionados con la sexualidad, la reproducción y por ende de los métodos de planificación familiar, son los amigos, es el medio de socialización más abierto que tienen los hombres, sin embargo, en ocasiones los mensajes sobre el uso de los diferentes métodos de planificación se transmiten distorsionadamente, semitifica el conocimiento y al gunas veces se sobredimensiona, el uso lo asocian con falta de placer, esterilidad, aparecimiento de enfermedades, traición de unos y otros en las relaciones sexuales.

A unque en menor proporción la consulta reporta que loshombres padres y no padres tienen como fuente de información de los métodos de planificación la esposa o compañera de hogar (7.2\%). Desde su aparecimiento las campañas de planificación han estado dirigidas hacia las mujeres, es hasta con el surgimiento del SIDA que la estrategia promocional cambia y se proyecta con más fuerza hacia los hombres, pero siempre el espacio por excelencia de socialización de temas relacionados con la sexualidad y la reproducción en los hombres son los amigos, así lo reporta la consulta (46.8\%) seguida por los Centros de Salud (44.8\%), los M edios de Comunicación (42.9\%) y losmenosmencionados, por su orden son: Ias O N G $(2.9 \%)$ y la esposa (7.2\%).

A pesar que la mayoría de los encuestados ( $81.7 \%$ ), dijo estar de acuerdo en que los hombres y las mujeres deben usar métodos anticonceptivos para evitar embarazos si no se desea tener un hijo, a nivel de país la Encuesta N acional de Epidemiología y Salud Familiar (EN ESF) refleja lo contrario, especialmente cuando se trata de población adolescente, la tasa de fecundidad de las adolescentes es relativamente alta (135 nacimientos por cada 1,000 adolescentes). En el país el 19\% de los partos atendidos por los servicios de salud pública son adolescentes (Jóvenes en C ifras, 1997).

“....Si uno no puede ponerle paro a eso..., debe usar métodos anticonceptivos y si por eso de la mala suerte no funciona por un error $X$ pues abstinencia papa..., porque si no, más paquetitos...".

( Hombre no padre, sector urbano, clase media)

“.... M irá, yo creo que la decisión y la responsabilidad es de los dos; pero yo creo que en la mayoría de los casos tendría que ser yo quien tome la precaución, por la misma sociedad, porque para las mujeres es mucho más difícil..."

( Hombre no padre, sector urbano)

0 tra forma de significación referente a la proposición: tomar precauciones o no para evitar tener hijos, deriva de las relaciones de género existentes en la cultura hon dureña, en donde un número elevado de hombres ejerce un al to grado de poder, por consiguiente ellosson dueños de las decisiones que a nivel de pareja deben tomarse referente a la planificación de la familia, ello esuno de los factores que inciden en el alto nivel de fecundidad de las mujeres, contribuyendo con esta forma de comportamiento a la existencia de familias numerosas, con pocas posibilidades económicas para darle a los hijos e hijas una vida digna, aumento del trabajo de las mujeres y sobre todo un alto deterioro de su salud. El 16.3\% no está de acuerdo en tomar precauciones y en menor proporción dudan o no saben.

Los hombres no padres de clase media universitarios participantes a un grupo focal consideran que es una responsabilidad de la pareja tomar medidas de protección, sin embargo, son de la opinión que en esta sociedad tan conservadora y con muchos controles resulta muy difícil para las mujeres solteras que viven con sus padres hacerlo ellas, por lo que los hombres deben tener la visión y la sabiduría de ser ellos quienes se protejan. También se percibe en ellos un grado mayor de compromiso, no se encuentra dentro de sus planes a corto plazo la paternidad, tienen como prioridad sus estudios.

"... Yo primero quiero terminar mi carrera, ... la verdad es que no está dentro de mis planes una relación formal, así que me protejo porque todo lo que me sale es puro vive... Yo solamente practico el sexo seguro... N o me arriesgo, ya me la tienen bien cantada mis viejos, que ellos no me van a mantener con mujer, ni hijos".

(H ombre no padre, clase media, sector urbano).

\section{Sobre el aborto}

Pese a que en $\mathrm{H}$ onduras todas las formas de aborto están penalizadas hasta con 8 años de cárcel, cada día cientos de mujeres arriesgan sus vidas para practicarse un aborto en la clandestinidad, las mujeres que se lo practican lo hacen con pocas o ninguna condición de higiene, sin los cuidados médicos necesarios, poniendo en riesgo su salud, incluso la vida. Se sabe que desde hace un poco más de 25 años el aborto es la segunda causa por la que mujeres egresan de los hospitales (M ujeres en cifras, 1997), año con año las muertes maternas registradas en los hospitales van en aumento, por ejemplo en 1994 el porcentaje de muertes maternas por aborto fue de $4.0 \%$ ya para 1997 había aumentado a 6.2\% (O liva, Victoria: 2002).

El aborto no es una práctica de la que las mujeres quieran hacer uso, se sabe que no es un método de planificación familiar, sin embargo, si lo llevan a cabo es porque se sienten atrapadas en una situación tal que ni los miedos ni las culpas ni los riesgos son suficientes para disuadirlas.

Ello indica que la solución al problema no está en la represión de la interrupción voluntaria del embarazo, sino en la modificación de las estructuras social es a otras más equitativas, en donde tanto la maternidad como la paternidad sean voluntarias y responsables en un espacio de salud y bienestar dignos de todo ser humano.

En Cairo, 1994 se planteó que las mujeres que tienen embarazos no deseados deben tener más fácil acceso a información fidedigna y a un asesoramiento comprensivo, se debe asignar máxima protección a la prevención de los embarazos no deseados y habría que hacer todo lo posible por eliminar la práctica del aborto. En H onduras cuando se atiende institucionalmente a una mujer por al gún pa- 
Cuadro No. 8. Representaciones de los Hombres sobre la Reproducción

\begin{tabular}{|lllll|}
\hline PROPOSICIONES & $\begin{array}{l}\text { DE } \\
\text { ACUERDO }\end{array}$ & $\begin{array}{l}\text { NO } \\
\text { ACUERDO }\end{array}$ & DUDO & NO \\
\hline $\begin{array}{l}\text { Las personas no deben } \\
\text { interferir en los embarazos } \\
\text { o los nacimientos porque la } \\
\text { vida es obra de Dios. }\end{array}$ & & & & \\
$\begin{array}{l}\text { El aborto no tiene ninguna } \\
\text { justificación y debe ser } \\
\text { condenado siempre. }\end{array}$ & 1,029 & 150 & 12 & 9 \\
\hline
\end{tabular}

Fuente: Encuesta CASC-UCA -FNUAP - CEPAL. Masculinidad y Paternidad, Honduras, mayo 2002.

2002 la Fiscalía especial de la mujer registró 6,034 denuncias entre las cuales las principales causas están la violencia intrafamiliar y las violaciones. (cuadro N o. 11).

Las opiniones de los hombres consultados pasan también por un discurso ético, control social, y una realidad de irresponsabilidad por parte de los hombres padres de los hijos abortados en cuanto a asumir compromisos frente al hijo por nacer, se sabe que la mayoría de los abortos que se practican las mujeres están relacionados, con violaciones, embarazo adolescente, abandonos de hogar, madres solteras, por los patrones culturales imperantes no se debería cul pabilizar a la mujer de un acto que tiene orígenes en la irresponsabilidad 0 en el delito masculino, a la mujer se le señala, se le condena incluso con

decimiento relacionado con el aborto, la generalidad de los médicos y enfermeras no les brindan la atención médica con profesionalismo y respeto, la atención pasa por un permanente cuestionamiento hacia la mujer paciente.

Culpabilizar a las mujeres por el aborto y reducirlo a un problema moral limita las posibilidades de comprensión y atención del problema. La respuesta de los hombres mayoritariamente si de acuerdo $(87.3 \%)$ a la proposición que afirma que el aborto no tiene ninguna justificación y debe ser condenado siempre, pone de manifiesto una fuerte influencia de una concepción que concede a las iglesias el derecho de prohibir lo malo e impulsar lo bueno en la sociedad, también es representativa de una mentalidad muy tradicional. Las personas no deben interferir en los embarazos o los nacimientos porque la vida es obra de Dios (85.8\%) si de acuerdo, igualmente es reflejo de esa mentalidad tradicional, que es predominante en las áreas rurales.

En la encuesta se presenta un acuerdo mayoritario entre los hombres consultados sin distinción de sector de residencia, condición de paternidad o rangos de edad que condena el aborto y además lo entiende como un proceso que afecta únicamente el cuerpo de las mujeres, sin embargo, mayoritariamente se está de acuerdo en que es asunto de la mujer el cuidarse para no quedar embarazada.

Esta forma de pensamiento descuida en el análisis el escenario en el que se desarrolla este hecho, la desigualdad sexual en las relaciones de pareja, el poder jerárquico de los hombres hacia las mujeres en donde existe una clara tendencia al control femenino, la existencia de delitos sexuales como la violación, la ignorancia o desinformación sobre los métodos de planificación familiar, pone en entredicho el papel del Estado pues es incapaz de proteger a las mujeres de los hechos que lasinducen a practicarse un aborto. En el año la cárcel, al hombre ni se le señala, ni se le condena ni se le mete a la cárcel.

\section{El mejor tiempo para ser padre}

La edad ideal para ser padre según lo manifestado por los hombres urbanos entrevistados se encuentra entre los 23 y 30 años, los hombres rurales consideran como la mejor edad, de los 15 a los 25 años. C omo se observa la mejor edad para ser padres en los hombres rurales es más temprana que en los urbanos y más avanzada en edad, que las mujeres.

Las entrevistas reafirman los resultados de la encuesta en la proposición si uno ya se gana la vida está preparado para ser padre ( $82.2 \%$ de acuerdo, $16.0 \%$ no de acuerdo, $1.3 \%$ duda y $0.6 \%$ no sabe), la mayoría de los entrevistados, opinó que el mejor tiempo para ser padre está asociado a la posibilidad de asumir una responsabilidad económica, con la obtención de un empleo, especialmente los del área rural, probablemente porque en ese sector las posibilidades para profesionalizarse son menores que en el sector urbano.

0 tra opinión de los varones del área rural es que los hijos se deben tener cuando se está joven, piensan que tienen pocas posibilidades de tener una vida prolongada. 0 tras asociaciones con el mejor tiempo para ser padre están relacionadas con la madurez mental y emocional del hombre y en la mujer, la madurez biológica; al tiempo de finalizar los estudios y adquirir una profesión o un oficio.

N o obstante, que la mayoría de los hombres consultados tienen dentro de sus aspiraciones la paternidad. Existen hombres que igual que no tienen como prioridad fundar una familia tampoco la tienen con la paternidad, esto es un reflejo de los cambios que están experimentando los hondureños en sus representaciones socioculturales. 


\subsection{Perfiles de la Visión de Sexualidad y Reproducción de los Hombres}

De la aplicación del análisisfactorial de correspondencias múltiples al resultado de la encuesta en los apartados sobre sexual idad y reproducción, a manera de síntesis, el escenario presenta tres perfiles o tipologías: el perfil de pensamiento tradicional androcéntrico, el perfil de pensamiento moderno favorable a la equidad de género y el perfil de pensamiento sobre la sexualidad y la reproducción en transición.

\section{El perfil de pensamiento tradicional androcéntrico}

Este grupo incluye el $37.08 \%$ de encuestados, este perfil se caracteriza por un pensamiento que considera que la sexualidad masculina es natural, que no se puede controlar, contraria a la sexualidad de la mujer. Este tipo de pensamiento avala la práctica sexual masculina con varias parejas sin asumir compromisos y un comportamiento irresponsable frente a la reproducción. M entalidad socialmente construida y reproducida por la sociedad patriarcal y sustentada en la ideología machista, que constituye la expresión más radical del patriarcado.

A parece asociado a encuestados que poseen bajo nivel educativo y que son residentes en el área rural.

\section{El perfil de pensamiento moderno favorable a la equidad de género}

Este perfil de pensamiento está representado por el $48.25 \%$ de encuestados, se identifica con un pensamiento actual, se inclina a una sexual idad con equidad entre hombres y mujeres desde una relación democrática y de respeto, que visualiza la sexual idad en función del placer tanto para el hombre como para la mujer. También se caracteriza por una visión de la reproducción planificada.

Esto podría indicar que se está originando un cambio en los modos de pensar de los hombres hondureños que se asocia a prácticas sexuales con equidad, aunque la visión mágico religiosa y androcéntrica de control de la reproducción es la prevaleciente, se visualizan modos de pensar favorables a la equidad de género en las determinaciones de la reproducción, las cuales pueden estar siendo influenciada por estímulos culturales externos.

A parece asociado a encuestados que poseen educación superior o secundaria, que están casados y que son residentes del área urbana.

\section{El perfil de sexualidad y reproducción en transición}

Este perfil de pensamiento está representado por el $14.67 \%$ de encuestados, es el que tiene un porcentaje menor.

Este tipo de mentalidad está asociada al cambio de una mentalidad de visión tradicional de la sexualidad y reproducción androcéntrica a una moderna.

Esta mentalidad en transición no se asocia a ningún tipo de variables ilustrativas que determinen su forma de pensar. Ello puede ser consecuencia de que este tipo de pensamiento puede ocurrir en individuos de diferentes características, que residen tanto en el área urbana como en el área rural, sin importar edad, condición de paternidad, nivel educativo u otra variable sociodemográfica

\subsection{Representaciones y Percepciones Sobre la Paternidad}

Se presentan a continuación las reflexiones resultantes de la opinión que tienen los hombres consultados sobre la paternidad. En la encuesta se formularon una serie de proposiciones con el propósito de descubrir la lógica de la construcción de la paternidad de los hombres hondureños a partir de las representaciones que los hombres y las mujeres tienen sobre la misma. Con el propósito de ahondar en el tema se realizaron entrevistas individuales y grupos focales con hombres y mujeres del área rural y del área urbana.

Este estudió trató de averiguar la mentalidad que subyace en los hombres hondureños a través de un enfoque sociocultural y de género, las representaciones que ellos se hacen sobre la paternidad y que se convierten en guías de sus comportamientos. Se trató de indagar la relación que existe entre la construcción social del varón y la representación mental de la paternidad en sus diferentes dimensiones. A sí como los factores que inciden en la forma de vivir la paternidad.

La paternidad es una interpretación del sujeto que lo ubica en relación con los hijos e hijas y comprende una serie de prácticas y significados. El posicionamiento respecto de loshijos ehijas comienza mucho antes de que éstos nazcan y se transforma desde que se proyecta el hijo o hija, ante el embarazo, el nacimiento del primer hijo y de los subsecuentes.

Los individuos afrontan la relación filial de forma distinta dependiendo del tipo de relación de pareja: si ésta es un encuentro ocasional, si son novios, si están casados, en una relación extramarital. A simismo, influye su situación laboral y económica. Los padres que asumen la paternidad lo hacen en distinto grado y en diversas formas, que van desde la construcción de vínculos afectivos amorosos hasta la violencia y la distancia afectiva, (A latorre, 2001).

\section{El ideal de padre}

Las percepciones que los varones consultados poseen sobre paternidad indican que los hombres tienen conciencia de lo que es un hombre como padre, se ponen de relieve todos los derechos que los hombres se adjudican ante la actitud de reproducir el tipo ideal de paternidad, dejan entrever una necesidad muy fuerte de identificarse con el estereotipo del buen padre. Los resultados de la encuesta contrastan con los model os cultural es y de género que se viven en la cotidianeidad, en la forma siguiente:

a) Que sea importante que el hijo lleve el apellido del padre (97.3\% de acuerdo). Indica la importancia que para los hombres posee la legitimidad de los hijos con una pareja estable, principalmente los hijos habidos dentro del matrimonio, de los hijos que tienen el privilegio de ser "hijos reconocidos". 0 bvia- 
mente esta respuesta no se relaciona con la realidad hondureña, en donde generacional mente han existido numerosos hijos e hijas ilegitimos-as, es hasta hace muy poco tiempo que la legislación ha abolido esa condición, sin embargo, cada día se inscriben en los registros civiles hijos e hijas sin el apellido del padre, con las consecuencias emocional es y material es futuras de no tener papá.

En general la mayoría de los hombres padres y no padres consultados $(71.6 \%)$ se manifiestan de acuerdo en que es natural que los hombres tengan hijos fuera del matrimonio.

b) La significancia que tiene: El hombre debe estar siempre presente al momento del parto de la mujer para apoyarla (95.0\% de acuerdo), cuando se sabe que no es una práctica cultural que los padres presencien el parto y cuando el parto se da en la casa de habitación, son mujeres las que sirven de parteras.

c) Q ue los padres deban asumir la crianza y atención de los hijos en ausencia de la madre ( $96.5 \%$ de acuerdo) es un ideal, son las abuelas y los abuelos, Ias tías o las hermanas mayores las que mayoritariamente han asumido y siguen asumiendo esa responsabilidad en ausencia de la madre.

d) Q ue los padres deban apoyar económicamente a sus hijos siempre, aunque la madre viva con otro hombre ( $94.9 \%$ de acuerdo) y que sea importante que el padre atienda las necesidades de los hijos aunque ya no lleve vida de pareja con la madre ( $97.8 \%$ de acuerdo) también es un ideal de padre porque es bien sabido que la mayoría de los hombres cuando se divorcian o se separan de la madre lo hacen también de los hijos, no pagan las pensiones alimenticias, no dan seguimiento al desarrollo de sus hijos, los visitan ocasional mente o no los visitan y es a la madre separada o divorciada a quien le toca asumir las responsabilidades paternas, sobrecargán dose de responsabilidades material es y emocionales ante la actitud de los padres de divorcio o separación también de los hijos.

Pero también Ilama la atención la significancia de una opinión dividida entre acuerdo y no de acuerdo ( $45.1 \%$ y $50.2 \%$ ) respecto de: U n padre no debe ser muy cariñoso y comprensivo porque puede perder autoridad y ser irrespetado por sus hijos e hijas. Ello es importante como indicios de cambios en las relaciones entre padres e hijos.

\section{Buen padre}

Respecto a quien es un buen padre, más de la mitad de los consultados (56.8\%) está de acuerdo en que es aquel que castiga y le pega a sus hijos e hijas cuando se portan mal, esa forma de pensar ha sido predominante en la representación tradicional del buen padre, quien se comportaba así salía del común del hombre padre hondureño.

Sin embargo, ya la imagen que se tiene del buen padre asociado al castigo, al que más pega, está empezando a cambiar. No se desconoce que los cambios están ocurriendo en los hombres de todos los estratos sociales, sin embargo, en este estudio los resultados de la encuesta y los testimonios dan cuenta de que es en la clase media donde se presenta el mayor número de casos, $(41.2 \%$ no de acuerdo, $1.7 \%$ duda y $0.4 \%$ no sabe).

"... Buen padre no solamente es ser un proveedor, sino que ser un orientador, un facilitador con los hijos... debe de tratar de ser un buen ejemplo, un buen modelo para que ellos puedan retomar las cosas positivas que uno pueda tener..."

(Padre urbano, clase media, con hijos biológicos y sociales)

". .U n padre responsable es aquel que cuida a sus hijos no importando si son de él, educándolos, dándoles una buena formación y haciéndolos una persona buena para este mundo..."

(Padre urbano, clase media, con hijos de una sola relación)

"... es el que mira por los hijos, el que les da de vestir, de calzar, de comer, estudios, todo..."

(Padre rural, clase popular, con hijos de múltiples relaciones)

\section{¿Quién hace qué?}

Prevalece en la mentalidad de los hombres las diferencias de género en cuanto al cuidado de los hijos, la mayoría de los consultados está de acuerdo en que son quehaceres de la madre cambiarle los pañales al hijo y darle de comer $(78.5 \%$ de acuerdo, $21.1 \%$ no de acuerdo), todavía se conserva el modelo tradicional de distribución de tareas domésticas por sexo, una diferenciación de responsabilidades entre padres y madres. Por esta diferenciación de tareas en el cuidado de los hijos la mujer madre es sobrecargada de responsabilidades incluso cuando se incorpora al trabajo remunerado, sea porque el aporte económico del compañero o esposo no ajusta para cubrir las necesi dades de los hijos e hijas o porque es parte de su realización personal.

El padre a la disciplina, a la regulación de la conducta, el informado, el transmisor de conocimientos políticos, docentes, culturales etc., sin embargo, una opinión dividida entre de acuerdo $47.8 \%$ y no de acuerdo $51.3 \%$ en que el cuido de los hijos es más responsabilidad de la mujer que de el hombre exterioriza la confusión en las que se desenvuelve la mentalidad de los hombres, por una parte se mantienen formas de pensar tradicionales, pero por otra, existen cambios en las relaciones entre padres e hijos. Sin embargo, prevalece entre padres y madres las diferencias de ¿quién hace qué?

\section{Responsabilidad paterna}

En la cultura patriarcal, cuando se trata de cuestionar comportamientos de irresponsabilidad, a la mujer se le señala y a los hombres se les dispensa, las opiniones de los consultados son un reflejo de este pensamiento: $M$ uchos hombres no se responsabilizan de los hijos por razones económicas ( $61.7 \%$ de acuerdo, 33.6\% no de acuerdo). Sin embargo, son de la opinión, que a través de la obligatoriedad de la ley los padres serían más responsables, o sea, que para ser responsable con los hijos es necesaria la existencia de un mecanismo coercitivo.

El 97.3\% de los encuestados está de acuerdo y 1.5\% no está de acuerdo en que: Independientemente de los problemas económicos que se 
tengan hay que apoyar y cuidar siempre a los hijos, en referencia a los hijos de parejas estables. $\mathrm{N}$ o se excluye la existencia de hombres padres que dan apoyo a los hijos que tien en fuera de la pareja estable o del matrimonio, aunque estos casos se presenten excepcionalmen- te ya que las estadísticasnacionalesindican un progresivo crecimiento de hogares con jefatura femenina donde los hijos son responsabilidad económica de la mujer.

\section{Cuadro No. 9. Representaciones de los Hombres sobre la Paternidad}

\begin{tabular}{|c|c|c|c|c|}
\hline PROPOSICIONES & DE ACUERDO & NO DE ACUERDO & DUDO & NO SABE \\
\hline $\begin{array}{l}\text { El cuido de los hijos es más responsabilidad } \\
\text { de la mujer que del hombre }\end{array}$ & $\begin{array}{l}573 \\
(47.8 \%)\end{array}$ & $\begin{array}{l}615 \\
(51.3 \%)\end{array}$ & $\begin{array}{l}8 \\
(0.7 \%)\end{array}$ & $\begin{array}{l}4 \\
(0.4 \%)\end{array}$ \\
\hline El hombre es quien debe dar dinero para los hijos & $\begin{array}{l}998 \\
(83.2 \%)\end{array}$ & $\begin{array}{l}195 \\
(16.3 \%)\end{array}$ & $\begin{array}{l}5 \\
(0.4 \%)\end{array}$ & $\begin{array}{l}2 \\
(0.2 \%)\end{array}$ \\
\hline $\begin{array}{l}\text { Si un hombre embaraza a una mujer el hijo } \\
\text { que nazca es responsabilidad de ambos }\end{array}$ & $\begin{array}{l}1,166 \\
(97.2 \%)\end{array}$ & $\begin{array}{l}33 \\
(2.8 \%)\end{array}$ & $\begin{array}{l}1 \\
(0.1 \%)\end{array}$ & $\begin{array}{l}0 \\
(0.0 \%)\end{array}$ \\
\hline $\begin{array}{l}\text { Son quehaceres de la madre cambiarle los pañales } \\
\text { al hijo y darle de comer }\end{array}$ & $\begin{array}{l}942 \\
(78.5 \%)\end{array}$ & $\begin{array}{l}253 \\
(21.1 \%)\end{array}$ & $\begin{array}{l}4 \\
(0.3 \%)\end{array}$ & $\begin{array}{l}1 \\
(0.1 \%)\end{array}$ \\
\hline $\begin{array}{l}\text { Es importante que el padre atienda las } \\
\text { necesidades de los hijos aunque ya no lleve vida } \\
\text { de pareja con la madre }\end{array}$ & $\begin{array}{l}1,163 \\
(97.8 \%)\end{array}$ & $\begin{array}{l}21 \\
(1.8 \%)\end{array}$ & $\begin{array}{l}5 \\
(0.4 \%)\end{array}$ & $\begin{array}{l}1 \\
(0.1 \%)\end{array}$ \\
\hline $\begin{array}{l}\text { El hombre debe estar siempre presente al momento } \\
\text { del parto de la mujer para apoyarla }\end{array}$ & $\begin{array}{l}1,140 \\
(95.0 \%)\end{array}$ & $\begin{array}{l}44 \\
(3.7 \%)\end{array}$ & $\begin{array}{l}10 \\
(0.8 \%)\end{array}$ & $\begin{array}{l}6 \\
(0.5 \%)\end{array}$ \\
\hline Es importante que el hijo lleve el apellido del padre & $\begin{array}{l}1,168 \\
(97.3 \%)\end{array}$ & $\begin{array}{l}30 \\
(2.5 \%)\end{array}$ & $\begin{array}{l}1 \\
(0.1 \%)\end{array}$ & $\begin{array}{l}1 \\
(0.1 \%)\end{array}$ \\
\hline Un padre debe dar caricias y cariño a sus hijos & $\begin{array}{l}1,175 \\
(97.9 \%)\end{array}$ & $\begin{array}{l}22 \\
(1.8 \%)\end{array}$ & $\begin{array}{l}2 \\
(0.2 \%)\end{array}$ & $\begin{array}{l}1 \\
(0.1 \%)\end{array}$ \\
\hline $\begin{array}{l}\text { Muchos hombres no se responsabilizan de los } \\
\text { hijos por razones económicas }\end{array}$ & $\begin{array}{l}740 \\
(61.7 \%)\end{array}$ & $\begin{array}{l}403 \\
(33.6 \%)\end{array}$ & $\begin{array}{l}47 \\
(3.9 \%)\end{array}$ & $\begin{array}{l}9 \\
(0.8 \%)\end{array}$ \\
\hline $\begin{array}{l}\text { Los padres deben asumir la crianza y atención } \\
\text { de los hijos en ausencia de la madre } \\
\text { Lo más importante para el hombre en la vida }\end{array}$ & $\begin{array}{l}1,158 \\
(96.5 \%)\end{array}$ & $\begin{array}{l}38 \\
(3.2 \%)\end{array}$ & $\begin{array}{l}2 \\
(0.2 \%)\end{array}$ & $\begin{array}{l}2 \\
(0.2 \%)\end{array}$ \\
\hline es ser padre & $\begin{array}{l}991 \\
(82.6 \%)\end{array}$ & $\begin{array}{l}186 \\
(15.5 \%)\end{array}$ & $\begin{array}{l}18 \\
(1.5 \%)\end{array}$ & $\begin{array}{l}5 \\
(0.4 \%)\end{array}$ \\
\hline $\begin{array}{l}\text { Un buen padre es el que apoya económicamente } \\
\text { a los hijos y le da cariño a sus hijos }\end{array}$ & $\begin{array}{l}1,161 \\
(96.8 \%)\end{array}$ & $\begin{array}{l}36 \\
(3.6 \%)\end{array}$ & $\begin{array}{l}2 \\
(0.2 \%)\end{array}$ & $\begin{array}{l}1 \\
(0.1 \%)\end{array}$ \\
\hline $\begin{array}{l}\text { Si uno ya se gana la vida está preparado } \\
\text { para ser padre }\end{array}$ & $\begin{array}{l}986 \\
(82.2 \%)\end{array}$ & $\begin{array}{l}192 \\
(16.0 \%)\end{array}$ & $\begin{array}{l}15 \\
(1.3 \%)\end{array}$ & $\begin{array}{l}7 \\
(0.6 \%)\end{array}$ \\
\hline $\begin{array}{l}\text { Los padres deben apoyar económicamente a sus } \\
\text { hijos siempre aunque la madre viva } \\
\text { con otro hombre }\end{array}$ & $\begin{array}{l}1,139 \\
(94.9 \%)\end{array}$ & $\begin{array}{l}40 \\
(3.3 \%)\end{array}$ & $\begin{array}{l}18 \\
(1.5 \%)\end{array}$ & $\begin{array}{l}3 \\
(0.3 \%)\end{array}$ \\
\hline $\begin{array}{l}\text { Los hombres serían más responsables con los hijos } \\
\text { si hubiera leyes que los obligaran }\end{array}$ & 989 & 131 & $\begin{array}{l}73 \\
(82.4 \%)\end{array}$ & 7 \\
\hline$(10.9 \%)$ & & & $(6.1 \%)$ & $(0.6 \%)$ \\
\hline $\begin{array}{l}\text { Un padre no debe ser muy cariñoso y comprensivo } \\
\text { porque puede perder autoridad y ser irrespetado } \\
\text { por sus hijos e hijas }\end{array}$ & $\begin{array}{l}541 \\
(45.1 \%)\end{array}$ & $\begin{array}{l}602 \\
(50.2 \%)\end{array}$ & $\begin{array}{l}47 \\
(3.9 \%)\end{array}$ & $\begin{array}{l}10 \\
(0.8 \%)\end{array}$ \\
\hline $\begin{array}{l}\text { Buen padre es aquel que castiga y le pega a sus } \\
\text { hijos e hijas cuando le tratan mal }\end{array}$ & $\begin{array}{l}681 \\
(56.8 \%)\end{array}$ & $\begin{array}{l}494 \\
(41.2 \%)\end{array}$ & $\begin{array}{l}20 \\
(1.7 \%)\end{array}$ & $\begin{array}{l}5 \\
(0.4 \%)\end{array}$ \\
\hline
\end{tabular}

Fuente: Encuesta CASC-UCA -FNUAP - CEPAL. Masculinidad y Paternidad, Honduras, mayo 2002. 


\subsection{Representaciones y Percepciones Sobre la Filiación}

Los hijos dan sentido a la vida del padre. Si de acuerdo $98.3 \%$,Tener un hijo estener por quien luchar en la vida, si de acuerdo $98.7 \%$ el hijo es producto del amor de la pareja. Si de acuerdo $94.6 \%$, los hijos son una bendición de Dios. Si de acuerdo 98.7\%

Los significados que los hombres tienen sobre al gun as proposiciones referente a los hijos, al reconocimiento paterno ( sea o no el padre genitor biológico) son correspondientes con la necesidad de identificarse con el patrón del ideal de padre, existe en ellos una necesidad muy fuerte de identificarse con la imagen del padre ideal.

Los padres prefieren el hijo varón porque garantiza mantener el apellido.

Si de acuerdo 56.8\%.Tener un hijo es muestra de que se es hombre. Si de acuerdo $41.8 \%$.

Tener muchos hijos ayuda a garantizar la sobre vivencia de la familia. Si de acuerdo 53.0\%

L os hijos se tienen para garantizar la seguridad de los padres en la vejez. Si de acuerdo $70.5 \%$

$\mathrm{N}$ o obstante, existen padres que tienen preferencias en cuanto a tener hijas o hijos. D esde la concepción, las diferencias entre hombre y mujer se manifiestan, la necesidad de trascender a través de perpetuar el apellido, simboliza en loshombres su necesidad de mantener el poder aún después de la muerte, prefieren al hijo varón porque les garantiza la trascendencia (56.8\% de acuerdo, 37.6\% no de acuerdo).

También existen hombres que asocian la paternidad con la hombría entre más hijos tenga más hombre se es, no importando si tiene la capacidad emocional y material para aten der las necesidades que impone traer un hijo o hija al mundo. A pesar que ese pensamiento ha variado y no corresponde a la mayoría (41.8\% de acuerdo) es un porcentaje significativo en cuanto a las consecuencias en la vida de pareja, en la vida de las mujeres madres y de los hijos. Familias empobrecidas por la alta fecundidad de sus padres, madres sobrecargadas de trabajo, hijos con pocas posibilidades de acceder a una mejor vida, a la educación porque se tienen que incorporar al trabajo para contribuir al sosten imiento de una familia numerosa, es resultado de esta forma de pensamiento.

En muy pocos casos, los hombres padres tienen la capacidad aunque sea material de mantener familias numerosas. A esta situación también se asocia el pensamiento tradicional que tener muchos hijos ayuda a garantizar la sobrevivencia de la familia (53.0\% de acuerdo, $41.5 \%$ no de acuerdo), sigue predominando el pensamiento de la sociedad agraria, tener más brazos para trabajar, los hijos y las hijas están destinados a trabajar aunque de forma diferente, y con valor diferente, los varones son más valiosos que las niñas porque el trabajo de ellos reporta ingreso, las niñas son útiles porque ayudan en la casa. En H onduras esta forma de pensamiento no es casual, pues a pesar de los cambios modernos, el país sigue manteniendo características de una sociedad agraria.

Se continúa reproduciendo la idea de que los hijos se tienen para garantizar la seguridad de los padres en la vejez ( $70.5 \%$ de acuerdo, $26.3 \%$ no de acuerdo), este pen samiento es contradictorio con la realidad que están viviendo las personas mayores, desprotegidas de servicios de seguridad social o de servicios de salud, en muchos casos abandonados por sus hijos e hijas, o en otros casos, a pesar de su ancianidad sirviendo de soporte económico de los hijos(as), ya no son los padres los que se van a vivir con los hijos en la vejez, son los hijos y las hijas aunque ya tengan formado un hogar los que se van a vivir con el padre o con la madre, no porque los quieran cuidar sino porque las dificultades económicas no les permiten tener la posibilidad de costear los gastos de vivir independientes. En la sociedad moderna el amor filial y los valores de solidaridad se están perdiendo.

"... Yo deseaba tener a mi hija porque yo decía que algún día ella me iba a ayudar..."

(Padre rural, clase popular, con hijos de múltiples relaciones).

\section{La contradicción del discurso}

A continuación se presentan al guno testimonios de los padres y madres consultado/as, los testimonios aportados son contradictorios con la mentalidad dominante expresada en la encuesta, pero no necesariamente reflejan discursos mentirosos. Puede ser que expresen el porcentaje de padres que han ido cambiando de mentalidad y cuya existencia es también reflejada por los resultados de la encuesta.

Es común en contrar varias categorías de hijos y varias categorías de responsabilidades:

\section{Los hijos de la casa y los hijos de afuera}

"... A los hijos de afuera los tomo en cuenta, son mis hijos también y les ayudo cuando puedo..."

(Padre rural, clase alta, con hijos de múltiples relaciones)

"... la relación con los hijos de mi esposa que no son míos, al principio fue difícil porque la relación con el padre de ellos no era buena conmigo y yo actuaba no correctamente, pero con el tiempo él se alejó y yo los adopté como míos. .." "(Padre rural, clase alta, con hijos biológicos de una relación e hijos sociales).

\section{Los de la juventud}

"... Yo no me arrepiento de los hijos que tuve por fuera, porque hay veces que uno joven comete muchos errores y cuando uno llega a una edad grande uno empieza a ir reconociendo todo aquello que ha cometido en error..."

(Padre rural, clase media, con hijos de múltiples relaciones)

En ese sentido las mujeres participantes a un grupo focal dijeron que una de las motivaciones que ellas tien en cuando demandan por alimentos a los padres de sus hijos, es porque éstos tienen un comportamiento diferente con ellos después de haberse separado de ellas. Se comentó que en ocasiones hay hombres que les han dicho que son más importantes los hijos de su pareja actual.

Lo expuesto a lo largo de este apartado explica que la construcción social de la paternidad es consecuente con el pensamiento androcéntrico sobre la sexualidad y reproducción y que obedece a ese conjunto de estereotipos determinantes en la constitución de la masculinidad. 


\begin{tabular}{|lllll|}
\hline PROPOSICIONES & DE ACUERDO & NO DE ACUERDO & DUDO & NO SABE \\
\hline Los hijos dan sentido a la vida del padre. & 1.180 & 14 & 3 & 3 \\
& $(98.3 \%)$ & $(1.2 \%)$ & $(0.3 \%)$ & $(0.3 \%)$ \\
Tener un hijo es tener por quien luchar en la vida. & 1,184 & 14 & 2 & 0 \\
& $(98.7 \%)$ & $(1.2 \%)$ & $(0.2 \%)$ & $(0.0 \%)$ \\
Tener un hijo es muestra de que se es hombre. & 502 & 670 & 25 & 3 \\
& $(41.8 \%)$ & $(55.8 \%)$ & $(2.1 \%)$ & $(0.3 \%)$ \\
Los hijos se tienen para garantizar la seguridad & 846 & 315 & 33 & 6 \\
de los padres en la vejez. & $(70.5 \%)$ & $(26.3 \%)$ & $(2.8 \%)$ & $(0.5 \%)$ \\
El hijo es producto del amor de la pareja. & 1,135 & 45 & 12 & 8 \\
& $(94.6 \%)$ & $(3.8 \%)$ & $(1.0 \%)$ & $(0.7 \%)$ \\
Los hijos son una bendición de Dios. & 1,184 & 8 & 6 & 2 \\
& $(98.7 \%)$ & $(0.7 \%)$ & $(0.5 \%)$ & $(0.2 \%)$ \\
Tener muchos hijos ayuda a garantizar la & 636 & 498 & 53 & 13 \\
sobrevivencia de la familia. & $(53.0 \%)$ & $(41.5 \%)$ & $(4.4 \%)$ & $(1.1 \%)$ \\
Los padres prefieren el hijo varón porque garantiza & 682 & 451 & 49 & 18 \\
mantener el apellido. & $(56.8 \%)$ & $(37.6 \%)$ & $(4.1 \%)$ & $(1.5 \%)$ \\
\hline
\end{tabular}

Fuente: Encuesta CASC-UCA -FNUAP - CEPAL. Masculinidad y Paternidad, Honduras, mayo 2002.

\subsection{Perfiles de Paternidad de los H ombres}

De la aplicación del análisisfactorial de correspondencias múltiples al resultado de las encuestas en la sección correspondiente a la paternidad, a manera de síntesis se identificaron dos model os de pensamiento, uno tradicional y uno moderno, conceptos que ayudan agrupar las respuestas de los hombres entrevistados, según sus formas de percibir y reconstruir mentalmente sus experiencias de vida respecto a la paternidad.

\section{Perfil de paternidad construido por una masculinidad tradi- cional}

Este primer perfil de paternidad construido por una masculinidad tradicional, incluye al mayor número de encuestados (62.42\%). Está constituido por respuestas afirmativas a proposiciones que refieren a estereotipos de género conservadores.

A pesar de que en la realidad está desapareciendo la figura del proveedor masculino y la autoridad y el respeto paterno se han impuesto por la violencia, la imagen del padre protector, fuerte, proveedor y seguro, más los reafirmantes de una masculinidad estereotipada, soportan ideológicamente un modelo de paternidad basado en la supremacía del género masculino.

Entre las respuestas afirmativas a una construcción tradicional de la paternidad se encuentra un grupo de proposiciones que ratifican la supremacía masculina. Las respuestas si de acuerdo indican una expresión de machismo puro, que no tiene interés en revestirse de una doble moral, pues se acepta como un derecho masculino que el resto de las personas giren en torno a las necesidades de los hombres.
Este se reafirma con un conjunto de respuestas que ratifican proposiciones de estereotipos de género con servadores, es sumamente preocupante, en un medio que cada día irá exigiendo más cambios de comportamiento a los hombres de pensamiento tradicional.

A parece asociado a encuestados que poseen un bajo nivel educativo que apenas logra el nivel primario o que son analfabetos, que no se encuentran estudiando actualmente, que residen en el área rural y que tienen un trabajo temporal.

\section{Perfil de paternidad construido por una masculinidad moder- na}

El perfil de paternidad construido por una masculinidad moderna está determinado por el $37.59 \%$ de encuestados, que respondieron en desacuerdo a proposiciones que refieren a estereotipos de género tradicionales.

A pesar de la primacía de un perfil de pensamiento tradicional sobre la masculinidad y de un modelo de paternidad conservador construido a partir de estereotipos sexistas y de inequidad, resulta sumamente interesante una alta representación que disiente del estereotipo de paternidad tradicional.

Este comparte las necesidades de una sociedad más equitativa, pero también del desarrollo del afecto, entre los géneros, entre los padres e hijos y entre las parejas, un afecto, que no este únicamente asociado a lo sexual, sino que a la experiencia humana de la afectividad, también se deja expresar la inconformidad con la asignación de un rol económico que cada día tiene más exigencias y es más difícil de cubrir por el tipo de sociedad en que hoy se vive.

Esta visión constituye el germen de una nueva forma de rela- 
ciones social es de mayor responsabilidad y madurez, don de los hombres además de tener el derecho a asumir su afectividad asumen su responsabilidad frente al comportamiento sexual, la sexualidad masculina deja de predeterminarse naturalmente y al ser un acto conciente, racional, es sujeto de responsabilidad. (cuadro N o. 15).

\section{COMPORTAMIENTOS Y PRÁCTICAS DE LOS HOMBRES FREN- TE A LA SEXUALIDAD, REPRODUCCIÓN Y PATERNIDAD}

En H onduras el tema de la sexualidad y reproducción, especialmente la sexualidad masculina se ha estudiado muy poco, los escasos estudios que se conocen han priorizado el abordaje desde la mujer, por lo que la mayoría de los análisis e indicadores utilizados para implementar políticas públicas referentes a la reproducción se abordan a través de la mujer.

A I haberse convertido el SIDA en un problema de salud pública, se han establecido a nivel gubernamental y no gubernamental programas que dedican recursos al estudio de los comportamientos sexual es y reproductivos de la población, sin embargo, los mismos se han circunscrito a un abordaje desde la salud, prevención curación, sin explorar los aspectos socioculturales que subyacen tras esos comportamientos y que hagan posible una mejor comprensión y abordaje de estos aspectos.

El propósito de este capítulo es recuperar a partir de las encuestas con una serie de preguntas relacionadas respecto a la sexualidad, reproducción y paternidad, como las representaciones o mentalidades que los hombrestien en sobre estos tópicos se convierten en guías de su comportamiento, así como las implicaciones social es que estas prácticas conllevan.

\subsection{Comportamiento de los H ombres Frente a la Sexualidad.}

\section{La iniciación de la sexualidad}

En H onduras los hombres comienzan su actividad sexual a edades muy tempranas, siendo niños, con parejas con las que no necesariamente mantienen una relación afectiva. Desde la salud este hecho es muy riesgoso, los adol escentes están más expuestos a adquirir enfermedades de transmisión sexual. Según la EN ESF 2001 la edad mediana de la primera relación sexual de los hombres es de 16.7 años sin observarse entre 1996 y 2001 cambios sustancial es de comportamiento en ellos.

Los resultados de las entrevistas que apoyaron esta investigación respecto a la edad de la primera relación sexual responde a la media nacional, no obstante, se reconocen casos de hombres que tuvieron su primera relación sexual entre los 12 y 14 años, siendo más temprana en los varones del área rural.

"... ya a los 12 empieza uno a travesiar"

(H ombre padre, sector popular, área rural).

\section{Práctica sexual: relación de una o varias parejas}

U n fenómeno muy frecuente en $\mathrm{H}$ onduras es la ocurrencia de la paternidad con distintas parejas. Una práctica históricamente habitual en el comportamiento reproductivo de los hombres hondureños; la mayoría de los encuestados (54.7\%) expresó haber tenido hijos con varias mujeres.

"... Tengo cinco hijos en total, tres con mi esposa y dos hijos por fuera, el mayor lo tuve cuando todavía estaba soltero y el otro con una señora que tengo...."

(Padre urbano, clase popular, con hijos de múltiples relaciones)

\section{U tilización de métodos anticonceptivos}

Del total de hombres encuestados un bajo porcentaje $26.1 \%$ afirmó usar algún método anticonceptivo y el 19.5\% expresó que es su pareja quien los utiliza. En las prácticas sexual es existe una cultura de transferencia de responsabilidades del hombre hacia la mujer en cuanto a tomar medidas de protección para prevenir los embarazos, son ellas las que mayoritariamente lo hacen, en 2001, el $61.8 \%$ de mujeres en unión de 15 a 44 años, estaba usando algún método anticonceptivo (ENESF, 2001).

Según datos de la ENESF/EN SM - 2001, y bajo el entendido que los datos de $\mathrm{H}$ onduras son los más recientes, $\mathrm{H}$ onduras ocupa el segundo lugar en el uso de anticonceptivos después de EI Salvador, y el primer lugar en la región con respecto al uso de métodos naturales, los cuales no son tan eficaces como los modernos.

El uso de anticonceptivos y de condón en las relaciones sexuales es muy bajo, se está ante un complejo fenómeno de apropiación delos métodos anticonceptivos posiblemente por la fal ta de una adecuada política de educación sexual y reproductiva.

A I respecto el reciente estudio realizado en $\mathrm{H}$ onduras por la $C E P A L$ señala que a menudo los hombres imponen restricciones a las mujeres en el uso de anticonceptivos. U n comentario surgido en el grupo focal con mujeres urbanas refiere que muchas veces las mujeres se ven obligadas a usar métodos anticonceptivos a escondidas de sus parejas porque ellos no las dejan. Señalan que en al gunos casos es debido a desconfianza y en otros casos por sus creencias religiosas.

Por su parte en un grupo focal con hombres rurales se comentó que no esimportante usar métodos de planificación, tienen la creencia que son mal os para la mujer y que matan la naturaleza, otros comentarios surgidos son: se deben tener los hijos que D ios les dé; si se deja a las mujeres tomar esas pastillas es darles carta libre para que tengan otros hombres.

Como se dijo en el capítulo anterior la planificación de la familia no es un acontecimiento que culturalmente sea parte de la idiosincrasia de los hondureños. La práctica de la reproducción sin planificación es propia de una sociedad agraria y obedece a una cultura machista. 
La existencia de numerosos hijos sin padre, de hijos no deseados y de hijos producto de violaciones se deben precisamente a la cultura machista, a la forma en que la mayoría de los hombres conciben y practican las relaciones sexuales en donde no existe una comprensión clara de la reproducción y del uso de métodos anticonceptivos, ejerciendo una práctica reproductiva de riesgo.

La mayoría de los hombrestransfieren a la mujer la responsabilidad de tomar medidas de protección. Incipientemente al gunas instituciones gubernamentales y no gubernamentales que trabajan el tema de sexualidad y reproducción empiezan a hablar de los derechos reproductivos como un mecanismo que posibilite en hombresy mujeres un mejor abordaje de esta problemática.

La paternidad sin planificación es una práctica común en los hombres del medio rural, que denota un sentido de imprevisión. Se advierte en ellos poca preocupación por las consecuencias sociales que causa el no usar medidas de protección en las relaciones sexuales.

La paternidad sin planificación posterior alas relaciones sexuales reafirma el machismo y el control que los hombres ejercen sobre sus compañeras o amigas.

Los testimonios de al gunos de los hombres en trevistados dejan evidenciado el planteamiento anterior.

“...EI primer hijo que tuve no estaba planificado no..., esas son cosas que pasan. . . E se fue cuando estaba estudiando y fue fuera del matrimonio..."

(Padre rural, clase media, con hijos de múltiples relaciones)

"... Yo no se porque D ios le da tantos hijos a una..."

( $M$ ujer madre, una relación, clase popular sector rural)

\subsection{Práctica de la Paternidad}

\section{Estructura familiar}

La familia hondureña históricamente ha sido una de las más numerosas de Centroamérica, el censo poblacional de 1988 mostró para $\mathrm{H}$ onduras una tasa de crecimiento poblacional de $3 \%$. En el año 2001 los datos oficiales reflejan que la tasa actual de crecimiento demográfico es de $2.6 \%$, y una baja leve en la tasa de fecun didad, no obstante, continúa siendo muy alta aún en relación con el área centroamericana, estos factores son elementos importantes en la constitución y mantenimiento de la familia.

Las familias numerosas son una característica propia de sociedades agrarias, en el campo se ha tenido la creencia de que "debajo del brazo de un hijo hay un pedazo de pan". Los hijos han constituido la figura de la fuerza de trabajo familiar, de hecho, las estadísticas indican que en el año 2001 el 12\% de la población ocupada corresponden a esta categoría ocupacional (INE, Septiembre: 2001).

O tra situación relevante para este estudio es que hace pocos años, hacia la década de 1930, la esperanza de vida al nacer apenas era de 43 años, las altas tasas de natalidad estaban asociadas a las probabilidades de sobrevivencia, por ello es permisible pensar que las familias numerosas, también cumplen la función de asegurar la trascendencia familiar.

\section{Edad en que fueron padres por primera vez}

Casi siempre la edad en que los hombres se convierten en padres por primera vez es más baja en el área rural que en el área urbana.

"... Yo ya a los 16 años ya tenía mujer y ya había tenido a la primera niña..."

(H ombre rural, sector popular de múltiples pareja)

\section{Si querían tener o no al primer hijo}

Generalmente los hijos tenidos en la adolescencia o en la juventud temprana no son parte de su proyecto de vida, son como dijo un entrevistado: travesuras. Es común entonces encontrar hombres padres ya a partir de los 15 años especial mente en el área rural donde inician más temprano la actividad sexual. La paternidad en estos padres no necesariamente supone la conformación de una familia, la toma de responsabilidades ni el reconocimiento de los hijos, generalmente las víctimas son los hijos y las mujeres.

C asi todas las mujeres participantes en el grupo focal manifestaron que cuan do salieron embarazadas por primera vez no lo esperaban, no estaba dentro de sus planes, ni siquiera lo habían conversado con sus compañeros o sus esposos. A Igunas dijeron que en ese momento lo que estaban viviendo era una relación de noviazgo sin miras a constituirse en una pareja estable, cuanto menos formar una familia. Sin embargo, pese a que no en todos los casos los hombres estuvieron dispuestos a enfrentar la paternidad, para ellas el hecho de ser madres significó un gran acontecimiento en sus vidas: ...bien alegre por el niño, yo ya quería tener mi niño, pero también significó como dijo una de ellas... más pobreza,... trabajaba todo el día y toda la noche, aunque el papá de los niños me ayudara con un poquito.

"... Yo no quería..., N o, no... o sea, que es como una etapa que uno pasa y no está preparado para lo que viene, hasta que se dan las situaciones uno se da cuenta en lo que falló o no..."

(Hombre padre clase popular, con hijos de múltiples relaciones, área urbana).

"... En realidad no a todos, porque los otros fueron producto de un accidente, de un error de la juventud..."

(Padre rural, clase alta, con hijos de múltiples relaciones)

".... o creo, ya que por travieso nació, ahora los del matrimonio actual, si quería mi primer hijo..."

(Hombre padre, clase alta, con hijos de múltiples relaciones, sector urbano).

Diferentes formas de vivir la paternidad

Dependiendo de la mujer con que se viva

así es la importancia que los

hombres le dan a sus hijos. 
Las participantes en el grupo focal de mujeres urbanas comentaron que el comportamiento del hombre con sus hijos varía según la relación que tienen con las parejas.

C uando el hombre ya no tiene relacionesmarital es con su compañera o esposa, tiende a ser cada vez más distante con sus hijos. Generalmente brindan ayuda económica cuando mantienen relaciones de pareja, a medida que se van distanciando de la mujer, en esa misma medida se van distanciando de loshijos. Entre las mujeres divorciadas o separadas de $\mathrm{H}$ onduras existe el dicho: "cuando se divorció de mi, se divorció de los hijos".

U n comentario surgido por una de las participantesa un grupo focal con mujeres fue: cuando estaba con él galán que me les daba a los cipotes, hasta me tenía enganchada que le trajera la partida porque me iba a reconocer a la niña mayor, . . A h porque a ella no me le dio el apellido, ya con el segundo si lo reconoció. M ire todo fue que nos dejáramos que ya no me les ayuda a los cipotes, bueno entonces por eso es que lo tengo embargado porque a mi se me hace todo, ah y la niña mayor que es enferma y tengo que pasarle comprando las medicinas ya no lo voy a seguir esperando, ay pero me da tanta pena ir a cobrar, otros comentarios hicieron referencia a las dificultades que pasan las mujeres separadas debido a que ya no cuentan con el apoyo de los hombresni en loseconómico, ni para atender a sus hijos.

C uando las mujeres se quedan solas con sus hijos, no tienen oportunidades de empl eos bien remunerados y los hombres se desentienden de sus responsabilidades económicas, aparecen las dificultades para proporcionar una infancia normal a los hijos e hijas, en $\mathrm{H}$ onduras una quinta parte de los hogares tien e como jefe de familia a una mujer, está aumentando significativamente el número de niños menores de 18 años que trabajan.

El estudio Panorama General de Empleo en Honduras, citado en la estrategia de Reducción de la pobreza plantea que el trabajo infantil refleja en buena parte la insuficiencia de ingreso de los hogares, o la falta de un padre que se responsabilice de los gastos que ocasiona la crianza y cuidado de los hijos e hijas. Según el Plan de A cción N acional Para la Erradicación del Trabajo Infantil en $\mathrm{H}$ onduras existen 491,740 niños trabajadores. Esta situación los convierte en candidatos a la deserción y la repitencia escolar. A umenta fuertemente el número de niños que viven en la calle, en la miseria, y sometidos a todo tipo de abusos y riesgos. Estos son una expresión límite de la incapacidad del núcleo familiar de proporcionar a los hijos e hijas las condiciones necesarias para una vida digna.

El papel de "proveedor económico" del padre a sushijos esquizá el más discutido, por las implicaciones inmediatas que tiene en el acceso a bienes y servicios necesarios en la calidad de vida material de los hijos. Sin embargo, los otros papeles como el de socialización, dar afecto, educación son quizá mucho más importantes para el desarrollo de la personalidad de los niños y las niñas los cuales son poco ejercidos por una gran parte de los hombres hondureños.

\subsection{EI Proceso de Socialización}

La socialización como proceso de aprender lo necesario de las costumbres y tradiciones para formar parte de la sociedad es en gran medida un proceso de enseñanza del comportamiento señalado por el rol. Es decir que cada persona debe formarse para desempeñar roles como niño, estudiante, marido, padre etc. H orton y H unt, 1988. Debido a la división sexual del trabajo y a la asignación de funciones diferentes tanto a los hombres (productor), como a las mujeres (reproductoras), en el proceso de socialización del niño influyen tanto la madre como el padre, sin embargo, en vista que el propósito de este estudio no es indagar sobre la construcción de la paternidad a partir de la socialización, se limita a presentar las representaciones que los encuestados tienen de sus padres y su comportamiento presente en relación a la práctica de la paternidad.

Este apartado presenta a partir de consideraciones sobre la socialización, las relaciones de los encuestados con sus padres en su niñez, con el propósito de encontrar explicacionesal comportamiento filial de los hombres, interesa rescatar las representaciones de los hombres encuestados y entrevistados sobre la paternidad, a partir del recuerdo que tienen del comportamiento de sus propios padres y el comportamiento que tienen ellos en la actualidad como padres, tratando de rescatar si el modelo de padre tiende a repetirse.

\section{¿Con quién vivió el informante?}

En las entrevistas que apoyaron esta investigación la imagen que los entrevistados evocan de sus padres es la del estereotipo del hombre en el que recae la autoridad dentro y fuera del hogar, por lo general la autoridad paterna está muy asociada al castigo, las prohibiciones y en muchos casos a las situaciones violentas provocadas por el al coholismo. M uchos asocian la forma de actuar de sus padres con el hecho de provenir de áreas rurales y su limitado acceso a la educación.

La presencia de la figura paterna en la etapa de formación del niño y de la niña es un factor determinante en el comportamiento futuro de los hombres y mujeres. Los patrones de socialización tienden a repetirse.

El porcentaje de los consultados que vivió con el padre es al to $(67.2 \%)$, que es el resultado de sumar los que vivieron con sus dos padres (62.9\%) y los que vivieron solamente con su padre $(4.3 \%)$. El $32.7 \%$ de los encuestados no vivió con su padre durante su niñez. $\mathrm{G}$ eneral mente son los hijos de padres que están divorciados, separados, o que viven en unión libre.

El porcentaje de hombres que no vivió con sus padres posiblemente haya tenido un proceso de socialización inadecuado, en donde la ausencia paterna pudo haber incidido positiva o negativa en la forma de practicar la paternidad.

M ás de la mitad de los encuestados dijo que sus padres tuvieron hijos con distintas parejas. En las familias hondureñas el ausentismo paterno es una realidad presente, una quinta parte de los hogares hon dureños están jefeados por una mujer. 
Pese a que el papel de padre de la mayoría de los hombres hondureños está reducido al de proveedor, es sabido de la importancia que tiene la presencia paterna en el buen desarrollo físico, emocional e intelectual delos hijos e hijas. En Honduras un número considerable de niños y niñas es desatendido tanto emocional como económicamente por sus padres, se crían sin la presencia de la figura paterna tan importante en la etapa de la niñez y la adolescencia. LoS indicadores disponibles dan cuenta de diversos procesos de debilitamiento de las familias, crece el número de familias incompletas, con madres pobres solas, jefas de hogar. (cuadro N o. 16).

“... M i papá tuvo 29 hijos con distintas mujeres.... a la larga eso es ser machista o egoísta con uno mismo. ... la verdad decir que mi papá era responsable es bien difícil, porque si no lo fue conmigo, no se como fue con los otros hijos, ni como se llevaba con ellos..."

( H ombre padre de múltiples parejas, clase media, sector rural)

"Para mi papá tener varios hijos con varias mujeres lo hizo ser machista y al mismo tiempo ser irresponsable con su vida. I magínese, nunca se dio cuenta de lo que andaban haciendo sus hijos, que hice yo o que no hice... yo me involucro en eso como víctima,... sólo tenía el apoyo de mi madre".

( H ombre padre de múltiples parejas, clase media, sector rural)

\section{Padres proveedores}

U n al to porcentaje de los consultados recuerda a sus padres como hombres trabajadores, que nunca evadieron su rol de proveedores del hogar, y dedicaron sus vidas al cumplimiento de ese papel $(79.1 \%)$.

N o obstante, a no todos les ayudaban con la periodicidad que se necesita para cubrir las necesidades que genera la sobrevivencia familiar, especialmente la de los hijos. De los que dijeron que sus padres les ayudaban, $79.1 \%$ del cuadro No 33, al $81.13 \%$ le proporcionaban asistencia mensualmente, al 9.79\% le ayudaba ocasionalmente y al resto ( $9.37 \%$ ) lo hacía cuando podía.

A I hacer una lectura más desagregada, de los datos se observa que en casi la cuarta parte de los entrevistados, sus padres no participaron al menos de las responsabilidades económicas que conllevan la crianza y cuidado de los hijos.

\section{Las expresiones de afecto}

La socialización le asigna formas diferenciadas de comportamiento a hombres y a mujeres, los hombres son representativos de fuerza, poder y autoridad. La figura paterna se asocia con este actuar, es un signo de debilidad el mostrar cariño a los hijos, sin embargo, la mayoría de los hombres consultados recuerda a su padre como un hombre cariñoso con ellos durante su niñez (74.2\%).

El recuerdo de muestras de cariño por parte del padre durante la infancia, no necesariamente está relacionada al contacto físico (abrazos, besos caricias), las muestras de cariño de los padres por lo general consisten en regaños, consejos, comprarles ropa, un juguete, etc. Esas manifestaciones se guardan como el recuerdo del cariño paterno, la evidencia de que el papá lo quería. (Sánchez, 1995).

“... M i papá era bien estricto, nos enseñó a trabajar y lo mismo hago yo con mis hijos..."

(Hombre rural, clase popular con hijos de una relación)

“... M i papá siempre fue responsable, nunca nos faltó nada... pero un recuerdo negativo que tengo de él es que nunca fue a la escuela a reclamar mis calificaciones, ... Tampoco fue cariñoso. Con mis hijos trato de ser responsable económicamente como mi papá, pero soy cariñoso y preocupado por la educación de mis hijos..."

(H ombre urbano, clase media con hijos de una relación)

Como se ve en los testimonios anteriores las manifestaciones de cambio se observan en los hombres de clase media.

Interesa dejar constancia que a un poco más de la cuarta parte de la muestra $(25.8 \%)$ dijeron que sus padres no fueron cariñosos con ellos, hay que tomar en cuenta que cuando se trata de niños/as y de aspectos afectivos la trascendencia que ocasiona tener estas carenciasincide en el desarrollo de la inteligencia emocional, el aprendizaje, en la seguridad personal, la autoestima, en el desenvolvimiento social. Trasciende el ámbito personal.

Lo planteado aquí sugiere que a nivel más general se están experimentando pequeños cambios no significativos en los hombres hondureños en lo relacionado a la práctica de la sexualidad y la reproducción, no obstante, en las familias hondureñas se continúa reproduciendo el patrón predominante, reproducción de hogares con jefatura femenina que se encuentran en condición de pobreza. De tal suerte que la práctica de la masculinidad se encuentra en raizada en la cultura machista imperante que valida y permite el ejercicio de la paternidad irresponsable.

\section{CONCLUSIONES}

\section{Pluridad de Mentalidades}

En las percepciones sobre la visión del mundo se diferencian tres tipos de mentalidades: tradicional, moderna y en transición, se muestra un antagonismo entre la tradicional y la moderna. La mentalidad en transición se encuentra en un proceso de definición.

El pensamiento tradicional se caracteriza por tener una visión del mundo centrada en aspectos míticosy religiosos. El pensamiento moderno por tener un pensamiento másanalítico. Loshombres con un pensamiento en transición sobre la visión del mundo, aunque son los menos, son los hombres que han abandonado las formas tradicionales de religiosidad, se permiten poner en duda el esquema dominante del pensamiento mágico religioso, la existencia de la duda les podría colocar en una posición favorable hacia las relaciones de género equitativas.

Si bien es cierto que se observa un predominio de una mentalidad tradicional en los hombres hondureños entrevistados, ésta no se presenta de una forma homogénea. 
Los factores asociados que están incidiendo en las formas diferentes que se muestran en las mental idades de los hombres hondureños son el sector de residencia, el nivel educativo y la religión. A sí, las formas tradicionales de pensar sobre la visión del mundo están caracterizando más a hombres residentes en el área rural, los hombres residentes en las áreas urbanas tienden a una conformación de pen samiento determinado más por las experiencias humanas que por determinaciones divinas o sobrenaturales.

En función de la edad, la visión del mundo, los aspectos religiosos y sociales, el fenómeno de una mentalidad en transición se empieza a percibir con mayor representación en los de menor edad. Como tendencia se observa que los hombres jóvenes poseen una mentalidad menos conservadora que los de mayor edad.

La sexualidad masculina es el eje de la cultura machista y de máxima expresión de la supremacía masculina sobre las mujeres, es aquí donde se concentran la mayor parte de los derechos de los hombres legitimados por la sociedad, el Estado y la igl esia y los estereotipos bajo los cual es se justifica la supremacía mascul ina sobre la femenina.

La sexualidad es el campo específico dondelasjustificacionesa un comportamiento estrictamente social y cultural se adjudican a la naturaleza, son excusas de una falsa determinación natural sobre un comportamiento enajenado e irrespon sable frente a actos propios de la conducta humana.

Sobre la reproducción en consecuencia, es uno de los temas don de más conservadores se comportan los hombres encuesta, la reproducción asociada muy estrechamente a la vida de pareja y hogar, está determinada por la superioridad del hombre sobre las mujeres y los hijos.

En la opinión de los hombres sobre la sexual idad y la reproducción es observable una postura conservadora muy bien afincada en el marco valorativo del androcentrismo, todo lo relacionado a la sexualidad y reproducción está determinado por la percepción masculina bajo un estricto ejercicio masculino del poder.

Sobre la masculinidad es quizá el tema más controversial para los hombres. En sus afirmaciones se preten de reafirmar la supremacía masculina haciendo un fuerte uso de la ideología machista. Sin embargo, las practicas cotidianas los ll evan a aceptar procesos que en el discurso machista, estarían debilitando esa supremacía masculina.

La paternidad, en consecuencia está determinada por esas formas de pensar dominantes, es el campo donde se hace necesario recurrir a argumentos de una supremacía masculina, la doble moral del padre ideal, que cada vez más se debilita ideológicamente frente a las evidencias empíricas de la irresponsabilidad paterna. El discurso masculino sobre la paternidad es total mente congruente con la imagen ideal del padre.

El discurso masculino legitimado sobre la paternidad está constituido por dos elementos: la doble moral y el ciclo de la paternidad.

Sobre la doble moral, nuestra sociedad está diseñada para que sea aceptable social mente el no reconocer lo que se hace incorrectamente respecto de los patrones ideales, por ello es muy normal que existan discursos interiorizados personal y colectivamente que disten mucho de las prácticas cotidianas en que se sustentan esos discursos.

Sobre el ciclo de la paternidad, se revela cuando el discurso ideal de la paternidad se corresponde a los hijos/as de la pareja actual, es bien sabido que los hombres al divorciarse o separarse de la mujer también lo hacen de sus hijos y que los buenos padres principalmente lo son para los hijos de la mujer de la cual están enamorados, y con quien en ese momento viven en pareja, los otros hijos, por lo general no cuentan.

El perfil de paternidad prevaleciente es el tradicional que ratifica una mentalidad masculina apegada a valores tradicional es y estereotipos de género conservadores. Consecuente con un modelo de pensamiento tradicional sobre la sexualidad y la reproducción, la construcción social de la paternidad obedece a ese conjunto de estereotipos determinantes en la constitución de la masculinidad.

El perfil de paternidad construido por una masculinidad moderna está en desacuerdo a proposicion es que refieren a estereotipos de género conservadores y se disiente con el estereotipo de la paternidad tradicional. Los hombres portadores de este perfil, se pronuncian por la necesidad de una sociedad más equitativa, poder manifestar y hacer uso del afecto como una experiencia humana más.

En la filiación paterna se reafirma el discurso de la supremacía masculina y el de la paternidad ideal. Sin embargo, es de hacer notar que algo está pasando en la práctica que permite que los hombres reconozcan que tener un hijo ya no es muestra de ser hombre.

Los factores asociados a las percepciones masculinas y los perfiles derivados de ellas, están incidiendo en las formas de pensar acerca de la familia, donde preval ecen roles patriarcal es entre sus miembros con un modelo de jerarquía masculina como eje de articulación familiar. Los cambios más significativos se pueden identificar en torno a la determinación residencial y el nivel educativo.

\section{Prácticas}

Las prácticas de paternidad, están condicionadas por las representaciones y comportamientos de los hombres sobre la visión del mundo, sexualidad, la reproducción y la masculinidad.

Estas condiciones están determinadas por el proceso de socialización masculina cuyo rasgo significativo es la iniciación sexual como experiencia estrictamente personal, más bien prohibida y que carece del apoyo familiar y escolar que de un soporte educativo, cultural y personal diferente.

Se reproducen constantemente los valores de la agresividad sexual masculina que puede incluir la violencia y la pasividad femenina. A demás de las connotaciones de género que conllevan estas actitudes, tienen implicaciones sociales, familiares y personales de múltiples consecuencias. A demás se está afectando a la sociedad en 
su conjunto por un comportamiento sexual negligente, se está poniendo en peligro la vida de los hombres mismos, de sus compañeras de hogar y de sus hijos con la transmisión de enfermedades de al to riesgo para la salud individual y colectiva.

En términos general es podemos asumir que el pensamiento tradicional constituye una fuerza importante en la determinación del perfil de paternidad, siendo el tradicional androcéntrico el preponderante en la construcción social de la experiencia de la paternidad. Este perfil es el que ha justificado históricamente la irresponsabilidad paterna, bajo un pensamiento enajenado que aparentemente impide tomar conciencia de los efectos perversos de asumir una conducta básicamente social como determinada por la natural eza, circulo vicioso que convenientemente, reproduce la primacía masculina en la sociedad, sus derechos personales sobre los del resto de la sociedad, así mismo como la reproducción de su irresponsabilidad.

N o obstante, lo fuerte de la corriente tradicional de la masculinidad y de la paternidad, una parte de los hombres, enfrentan un proceso de evolución de conciencia social, constituyendo el perfil de un pensamiento moderno favorable a la equidad de género y un perfil en transición que no está totalmente de acuerdo con el pensamiento tradicional.

La existencia de estos tres perfiles indica la presencia de hombres que a pesar del fuerte control social se atreven a dejar de manifiesto su inconformidad con un patrón de comportamiento que si bien es cierto les ha dado privilegios, también los ha inhibido de la vivencia de experiencias humanas que no están determinadas por el sexo. Sin embargo lo más importante, es el reconocimiento de distintas maneras de concebir y representarse la paternidad.

El visualizar una sexualidad diferente, puede estar siendo influenciada por estímulos culturales externos donde los medios de comunicación masivos juegan un papel importante en la divulgación de información sobre otros patrones de comportamiento o de denuncias de los efectos negativos de una masculinidad tradicional. Pero también, la misma realidad socioeconómica ha cambiado lo necesario para permitir a estos hombres que su entorno ha cambiado, que hoy en día hay otras exigencias y experiencias que están determinan do cambios drásticos en las actuacion es personal es particularmente en relación a las mujeres y los hijos e hijas.

\section{RECOMENDACIONES}

El gobierno de $\mathrm{H}$ onduras desde las instituciones encargadas de abordar los temas relacionados con la familia, así como la sociedad civil, están de acuerdo en que el problema central que ataca a la mayoría de las familias hondureñas es la pobreza con todas sus manifestaciones y consecuencias. La práctica irresponsable de la paternidad la agrava aún más.

La paternidad irresponsable es un problema muy complejo, se trata de problemas interrelacionados vinculados directamente a los patrones culturales, a la educación, a las formas de socialización, a la fal ta de aplicabilidad de las leyes existentes y a la falta de una política de Estado que promueva desde diferentes ámbitos la paternidad responsable.

En ese sentido, es importante potenciar la participación de los hombres en su propia transformación, facilitar su participación individual y colectiva en las decisiones y actividades adoptadas para favorecerles, que les permita desde una perspectiva personal reflexionar sobre las consecuencias que conllevan la práctica de la paternidad irresponsable y las posibilidades de cambio. Por tanto, las instituciones del Estado dedicadas a trabajar la problemática de la familia, así como las organizaciones de la sociedad civil deberán propiciar espacios de refl exión que posi biliten la eliminación de ésta práctica. Lo importante es tomar decisiones concretas y viables sobre el problema, la gestión de las instituciones relacionadas jugará un papel importante en la implementación de las acciones.

Lograr el incremento del nivel educativo en la población hondureña, es fundamental en la estrategia de reducción de la pobreza. Se trata de lograr un mayor nivel educativo que provoque la transformación de las mentalidades de los hon dureños y hon dureñas para el logro de estadios de vida más justos y equitativos.

El sistema educativo nacional en todos los niveles y modalidades deberá adecuar los contenidos programáticos incorporando la enseñanza de la educación sexual y reproductiva, dando especial importancia al papel de los hombres y de las mujeres, al papel del padre y de la madre, la incidencia que tienen en la vida de sus hijos e hijas y la importancia de las relaciones entre los padres y los hijos, con el objetivo de promover cambios de conducta a corto, mediano y largo plazo en la población estudiantil.

El Estado, a través de las instancias encargadas de proteger la familia debe propiciar la implementación de políticas públicas que promuevan la práctica de la paternidad responsable, impulsando acciones hacia la equidad entre los hombres y las mujeres, especialmente en las relaciones de pareja, en el involucramiento en las responsabilidades genéricas en el ámbito doméstico y en las relaciones con los hijos e hijas.

Es importante destacar la necesidad de efectuar estudios nacional es a profundidad que hagan visible y cuantifiquen la carga económica que representa para el Estado hondureño la paternidad irresponsable, así como sus consecuencias en la pobreza y en la reproducción de la pobreza.

Es importante contar con una plataforma informativa sobre los comportamientos masculinos sobre la procreación y la paternidad que trascienda los ámbitos sexuales y reproductivos abordados por la Encuesta $\mathrm{N}$ acional de Salud M asculina.

$\mathrm{H}$ acer visible las consecuencias en los hijos e hijas de la práctica de la paternidad irresponsable mediante un proceso de difusión que involucre a los medios de comunicación, las instituciones educativas, los gobiernos locales, las iglesias y organizaciones de la sociedad civil. Con el propósito de informar, sensibilizar y movilizar, la 
opinión pública a grupos interesados y a las familias.

Es necesario sensibilizar a la opinión publica, realizar campañas de educación y promover un cambio de actitud a todos los niveles de la sociedad. Se trata de trabajar el tema de la paternidad irresponsable desde el punto de vista humano y social; partir del fortalecimiento de las instituciones vinculadas a la temática, dada la limitada experiencia en este campo será muy importante crear grupos de trabajo interinstitucionales para intercambiar opiniones y experiencias sobre el tema; crear espacios en donde los hijos y las hijas puedan presentar reclamos.

Las medidas para enfrentar la paternidad irresponsable en $\mathrm{H}$ onduras no pueden darse en el vacío, se requiere de un trabajo coordinado de las instituciones del Estado vinculadas con el tema, los gobiernos locales, las instituciones encargadas de impartir justicia y las organizaciones de la sociedad civil.

El proceso de fomento de la práctica de la paternidad responsable deberá involucrar diferentes determinaciones: judicial, legislación y política de Estado, condiciones familiares, concientización dela sociedad, Educación (revisión de currículo), formación de personal.

En la determinación judicial se deberá tratar de superar las barreras que impiden una transparente, pronta y oportuna aplicación de la leyes.

En la determinación legislativa, es necesario preparar las bases, concienciar a la población sobre la necesidad que tiene el país de contar con una ley de paternidad responsable, así como preparar la plataforma institucional en su momento para la implementación de la ley.

El Instituto $\mathrm{N}$ acional de la Familia INFA H y el Instituto $\mathrm{N}$ acional de la M ujer IN A M como las instituciones con mayor vinculación en la problemática están Ilamadosa jugar un rol protagónico en el impulso de las iniciativas que promuevan las acciones tendientes a transformar la práctica inadecuada de la paternidad. En el entendido que hasta hace poco todo lo relativo a la reproducción familiar, individual emocional y corporeal han sido tratadosen el ámbito privado y por tanto no relacionados en la inclusión de las políticas públicas.

N o obstante, en la actual idad se observa un mayor acercamiento desde las políticas estatal es que tienden a regular más estas esferas de la vida privada. Esta incursión por parte del Estado en este campo, requiere de nuevos espacios de análisis que permitan tener una intervención efectiva y de impacto positivo, por lo que estas instancias deberán asumir el reto de lograrlo.

Las políticas e intervenciones en el tema de la paternidad deberán partir de que existen distintas maneras de pensar y no sólo una y que por lo tanto las intervenciones deben asegurar recuperar esas diferencias de educación, residencia, edad y los perfiles culturales que pueden estar construyén dose.

U na Coordinadora interinstitucional que promueva la práctica de la paternidad responsable presidida por el IN FA H Y EL IN A M, podría facilitar la efectividad del comienzo de estas acciones. 